\title{
Large-scale paleoceanographic variations in the western Mediterranean Sea during the last 34,000 years: From enhanced cold-water coral growth to declining mounds
}

\author{
Claudio Stalder ${ }^{\mathrm{a}, *}$, Akram El Kateb ${ }^{\mathrm{a}}$, Agostina Vertino ${ }^{\mathrm{b}, \mathrm{c}}$, Andres Rüggeberg ${ }^{\mathrm{a}}$, Osvaldo Camozzi ${ }^{\mathrm{a}}$, \\ Claudius M. Pirkenseer ${ }^{\mathrm{a}}$, Jorge E. Spangenberg ${ }^{\mathrm{d}}$, Irka Hajdas ${ }^{\mathrm{e}}$, David Van Rooij ${ }^{\mathrm{c}}$, \\ Silvia Spezzaferri ${ }^{\mathrm{a}}$
}

\footnotetext{
a Department of Geosciences, University of Fribourg, Chemin du Musée 6, CH-1700 Fribourg, Switzerland

${ }^{\mathrm{b}}$ Department of Earth and Environmental Sciences, University of Milano-Bicocca, I-20126 Milano, Italy

${ }^{\mathrm{c}}$ Department of Geology and Soil Science, Ghent University, Krijgslaan 281 S8, B-9000 Gent, Belgium

d Institute of Earth Surface Dynamics, University of Lausanne, Building Géopolis, CH-1015 Lausanne, Switzerland

${ }^{\mathrm{e}}$ Laboratory of Ion Beam Physics, Swiss Federal Institute of Technology Zurich, CH-8093 Zurich, Switzerland
}

A R T I C L E IN F O

\section{Keywords:}

Foraminifera

Corals

Quaternary

Alboran

Isotopes

Trophic

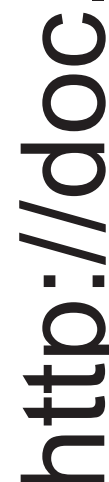

\section{Introduction}

Cold-water coral (CWC) ecosystems are hotspots of biodiversity that offer specialized habitats to many marine organisms (Freiwald et al., 2004; Margreth et al., 2009; Mastrototaro et al., 2010; Reolid et al., 2017). Frame-building CWCs settle mainly on subvertical walls, overhangs and pre-existing topographic highs where the hydrographic configuration favour sustained nutrient and food particle flow and prevent the corals from sediment smothering (e.g., White et al., 2005; Davies et al., 2009; Vertino et al., 2010). Living scleractinian CWCs thrive mainly along the world's continental margin in water depths ranging from a few tens to several thousands of meters (Freiwald et al., 2004). Their geographical distribution is also controlled by specific chemo-physical properties of the surrounding water masses such as density (Dullo et al., 2008; Freiwald et al., 2009) and dissolved oxygen content (Davies et al., 2008).

In the context of climate change and ocean acidification, framebuilding CWCs have become a topic of major scientific interest in the last two decades (e.g., Roberts et al., 2006; Turley et al., 2007; Movilla et al., 2014). Lindberg and Mienert (2005) and Titschack et al. (2015, 2016) have demonstrated that similarly to their zooxanthellate counterpart, scleractinian CWCs play a fundamental role in the total

\footnotetext{
* Corresponding author at: Federal Office of Public Health FOPH, Radiation Protection Division, Schwarzenburgstrasse 157, CH-3003 Bern, Switzerland.

E-mail address: claudio.stalder@bag.admin.ch (C. Stalder).
} 
carbonate budget and the regulation of atmospheric $\mathrm{CO}_{2}$ on Earth.

Cold-water corals and their associated fauna are known to have occurred in the Mediterranean Sea already since the Miocene as suggested by some outcrops on the Iberian Peninsula, the Maltese Archipelago, and Northern Italy (e.g., Taviani et al., 2005; Vertino et al., 2014). However, the development of marine organisms in the Mediterranean Sea is closely related to the water exchange with the Atlantic Ocean and thus of mean sea-level fluctuations and tectonic activity in the Gibraltar area. Several authors (e.g., Sabelli and Taviani, 1984; Sierro et al., 2003; Taviani et al., 2005; Dela Pierre et al., 2012) have demonstrated that the Messinian Salinity Crisis triggered by the periodic closure of the Strait of Gibraltar, impacted on the distribution of many marine organisms in the Mediterranean basins including the CWCs. The cosmopolitan and extant CWC taxa Lophelia, Madrepora and Desmophyllum are known from peri-Mediterranean regions since the Miocene but real carbonate frameworks made up by these genera have been recorded so far only since the Early Pleistocene (Vertino et al., 2014 and references therein). Living aggregations of the solitary coral Desmophyllum dianthus are rather common throughout the Mediterranean but CWC ecosystems dominated by living colonial corals (mostly Madrepora oculata) are only patchily distributed on topographic highs in the Alboran Sea (Hebbeln et al., 2009; Fink et al., 2013; Lo Iacono et al., 2014) and Ionian Sea (Corselli, 2010; Savini et al., 2014), along subvertical walls and overhangs (e.g., flanks of canyon fault escarpments) in the Gulf of Lions (Orejas et al., 2009; Gori et al., 2013), Ligurian margin (Tunesi et al., 2001), Strait of Sicily (Freiwald et al., 2009), Adriatic Sea (Freiwald et al., 2009; Sanfilippo et al., 2013) and Aegean Sea (Zibrowius, 1980; Vafidis et al., 1997).

Due to its peculiar configuration, the semi-enclosed Mediterranean Basin is strongly influenced by climate variability and humidity/aridity on land. The important supply of riverine and aeolian-induced detrital material to the deep basins results in unique marine sedimentary records providing information at centennial to millennial-scales on the Mediterranean's climate history (e.g., Cacho et al., 2001; Frigola et al., 2008; Fletcher et al., 2010; Liu et al., 2012; Ausín et al., 2015). One of the most prominent climate-driven events in the Mediterranean Sea is the deposition of sapropelic layers, which were formed during precession minima in the Earth's orbital cycles (Hilgen, 1991; Rohling, 1994) and in combination with decreased deep-water formation and elevated primary productivity (De Lange et al., 2008).

The periodic anoxia in the deep basins of the Mediterranean Sea has been well demonstrated by geochemical paleoredox proxies in sediment records such as Al-normalized Mn, U and V concentrations (MartínezRuiz et al., 2015 and references therein), as well as by the evidence in the benthic foraminiferal assemblage composition (e.g., Schmiedl et al., 1998, 2003; Abu-Zied et al., 2008).

Only few studies focusing on benthic foraminifera and ostracods associated with CWC ecosystems have been conducted so far (e.g., Margreth et al., 2009, 2011; Di Geronimo et al., 2005; Rüggeberg et al., 2007; Stalder et al., 2014, 2015; Sciuto and Rosso, 2015). Nevertheless, they clearly showed that the use of benthic microorganisms as a (paleo) proxy might be a powerful tool helping to decipher CWC evolution from the past to present. An overview of benthic foraminifera associated to CWCs and their associated fauna can be found in Spezzaferri et al. (2015).

Based on an integrated study of fossil micro- (benthic foraminifera) and macro-organisms (scleractinians) and geochemical data (stable carbon and oxygen isotopes of planktic and benthic foraminifera, Rockeval pyrolysis and stable carbon isotopes of the organic matter) of 2 gravity cores obtained from the Melilla Mounds Field (MMF; eastern Alboran Sea), we aim to testify if the hypothesis elaborated in the frame of the study of Stalder et al. (2015) are also valid in a regional context and get further insights: 1) in the past oceanographic and climatic configuration in the eastern Alboran Sea at mesopelagic depth, 2) on how climate and oceanographic variability at large to small-scales affected the CWC ecosystems in the Melilla Mounds Field and, 3) in the

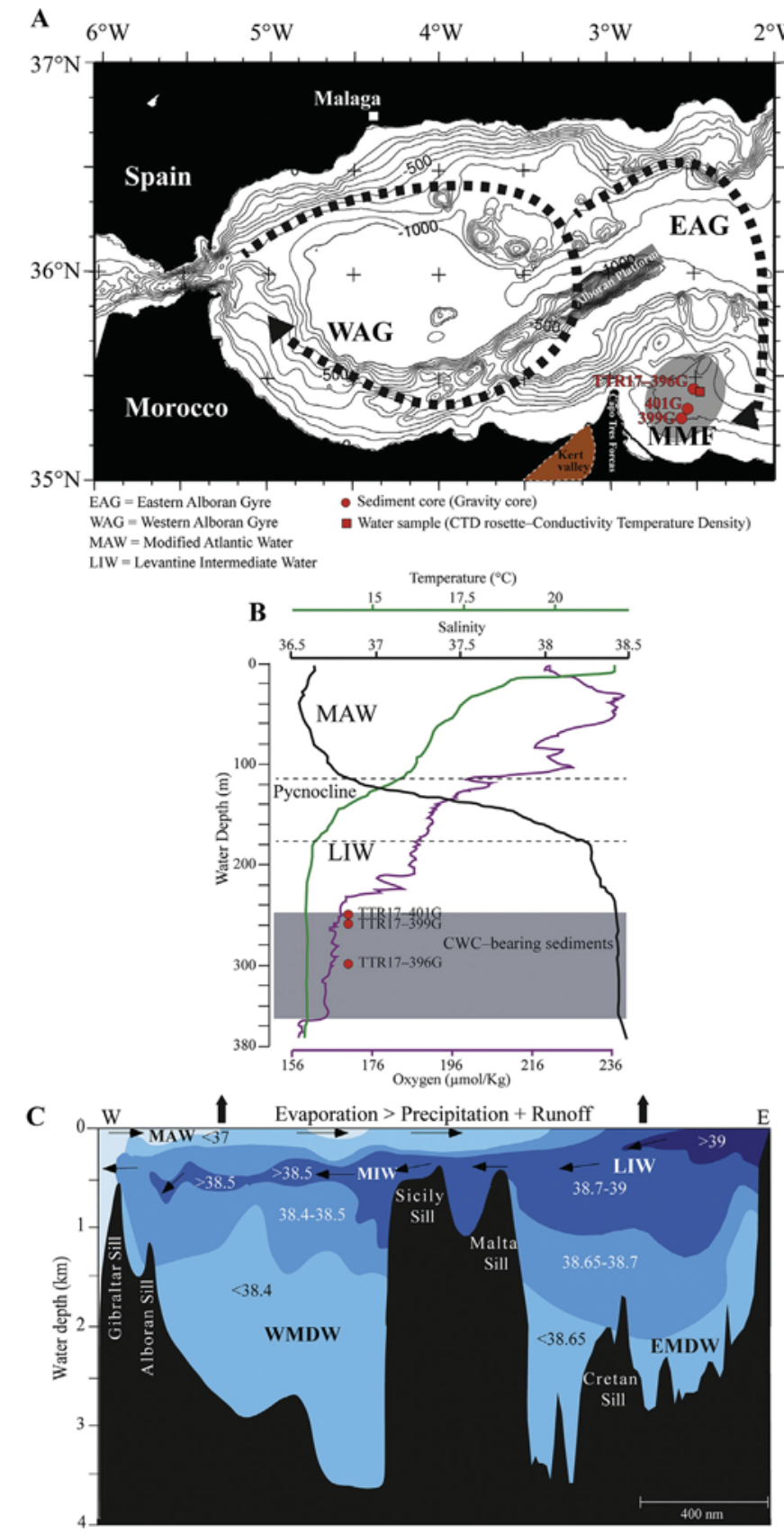

Fig. 1. A. Location map of the study area in the Eastern Alboran Sea. The shaded area shows the location of the CWC provinces Melilla Mounds Field (MMF). The brown dashed area close to the Capo Tres Forcas shows the location of the wadi Kert Valley. Is also shown is the general surface water circulation in the Alboran Sea with the Eastern and Western Alboran Gyres. B. CTD profile of the water column close to the Brittlestar Ridge I displaying the summer water mass configuration with the position of the Modified Atlantic Water and the Levantine Intermediate Water (Van Rooij et al., 2013). C. Vertical section plot of the Mediterranean Sea displaying major water masses and salinities (modified from Emeis and Sakamoto, 1998). MAW = Modified Atlantic Water; MIW = Mediterranean Intermediate Water; LIW = Levantine Intermediate Water; EMDW $=$ Eastern Mediterranean Deep Water; $\mathrm{WMDW}=$ Western Mediterranean Deep Water. (For interpretation of the references to colour in this figure legend, the reader is referred to the web version of this article.)

distribution pattern of the CWC community through time and space and test if any selective adaptation to environmental forcing among the taxa exists. 


\section{Geological and oceanographic settings}

The Alboran Sea is a $\sim 400 \mathrm{~km}$ long and $\sim 200 \mathrm{~km}$ wide basin located in the westernmost part of the Mediterranean Sea, restricted to the north by the Iberian Peninsula, to its westernmost end by the Strait of Gibraltar, to the south by the African continent and to the east by the Algerian-Balearic Basin. The Alboran Sea (Fig. 1) is characterized by complex seafloor morphology with several sub-basins, ridges and seamounts and water depths not exceeding $2000 \mathrm{~m}$ (Comas et al., 1999). The Melilla Mounds Field (MMF) is located in the southern Alboran Basin east of the Cape Tres Forcas (Fig. 1). The seafloor morphology of the MMF is characterized by clusters of CWC mounds and ridges, which cover a surface area of $\sim 100 \mathrm{~km}^{2}$ within a water depth range of 250-600 m (Comas and Pinheiro, 2007; Lo Iacono et al., 2014). Similarly to their counterparts in the north Atlantic, the mounds of the MMF form elongated and domed biogenic cold-water coral buildups (Fig. 1) with a width ranging from $48 \mathrm{~m}$ to $476 \mathrm{~m}$, up to $48 \mathrm{~m}$ high above the seafloor, displaying a maximum length of $649 \mathrm{~m}$ and mostly buried by a 1-12 m thick fine-grained sediment veneer (Lo Iacono et al., 2014).

In the northern part of the MMF, the relatively shallow $(200 \mathrm{~m}$ water depth) bank "Banc de Provençaux" is characterized at its edges by the occurrence of elongated ridges partially built up by cold-water coral mounds such as e.g., CWCs, sponges, bryozoans (Comas et al., 2009; Hebbeln et al., 2009; Fink et al., 2013). Video survey of this area has shown that most of these structures are exhibiting dead coral framework and rubble and that living CWCs are restricted to a few small colonies at their top (Hebbeln et al., 2009). North of the MMF, the Cabliers Site is a N-S oriented $6 \mathrm{~km}$ wide and $12 \mathrm{~km}$ long elongated bank of volcanic origin (Ammar et al., 2007) that harbour living CWC communities (Lo Iacono et al., 2014).

The water mass configuration is strongly related to the water exchange with the Atlantic Ocean through the Strait of Gibraltar and can be subdivided in three main water masses. The uppermost water mass $(0-220 \mathrm{~m})$ consists of Modified Atlantic Water (MAW), which is triggered by a jet of Atlantic water passing through the Strait of Gibraltar and describing two anticyclonic gyres in the Alboran Sea; the eastern Alboran Gyre (EAG) and the western Alboran Gyre (WAG) (La Violette, 1986). The two gyres are roughly situated over the western and eastern Alboran basins (Fig. 1) with respective maximum depths of 1200 and $1800 \mathrm{~m}$ and separated from each other by the Alboran Ridge (Renault et al., 2012). In summer, both gyres are stable, but in winter the WAG often migrates eastwards and the EAG eventually disappears due to the combination of elevated MAW inflow and MOW outflow with stronger westerly winds (Heburn and La Violette, 1990). The MAW is characterized by relatively lower salinities $(S<36.5)$ at its entrance into the Alboran Sea and becomes gradually saltier with respect to its residence time and mixing with Mediterranean water (Fig. 1; Font et al., 1998). The intermediate water mass is composed of Levantine Intermediate Water (LIW), originally generated in the eastern Mediterranean Sea and flowing towards the west below the MAW at a depth interval between $\sim 220-1100 \mathrm{~m}$ (La Violette, 1986). The LIW is characterized by temperatures of $\sim 13.1-13.2^{\circ} \mathrm{C}$ and salinities of $\sim 38.5$ (Millot et al., 2006, and references therein). The Western Mediterranean Deep Water (WMDW) fills the lowest part of the Alboran Basin and represents, together with the LIW, the main source of Mediterranean Outflow Water (MOW) which flows up to the Rockall Channel after its exit through the Strait of Gibraltar (Iorga and Lozier, 1999). Deep-water formation occurs in the Gulf of Lion and is a tributary of the regional circulation pattern, the initial density of the MAW and the LIW and wind strength (Cacho et al., 2000). The Western Mediterranean Deep Water has a temperature of $\sim 12.8-12.9^{\circ} \mathrm{C}$ and salinities of $\sim 38.42-38.45$ in the western Mediterranean sub-basins (van Haren and Millot, 2004).

Although the Mediterranean Sea is usually considered as oligotrophic, the Alboran Sea can be regarded as an exception with global primary production values of about $215-250 \mathrm{~g} \mathrm{C} \mathrm{m}^{-2} \mathrm{yr}^{-1}$ (Antoine et al., 1995; Bosc et al., 2004). In particular, two areas of high primary productivity have been recognized (Van Wambeke et al., 2004). The first area is situated on the northern limb of the WAG, where westerly winds cause the upwelling of nutrient-rich subsurface waters off Malaga and the second along the Almeria-Oran Front system in the eastern part of the Alboran (Sarhan et al., 2000; Baldacci et al., 2001; Fabrés et al., 2002).

At present day, the CWC mounds of the MMF sampled for this study occur well within the LIW in water temperatures of about $\sim 13.1{ }^{\circ} \mathrm{C}$ and salinity of $\sim 38.4$ (Fig. 1; Van Rooij et al., 2013). During summer, the dissolved oxygen concentrations in our study area reach values of -164-169 $\mu \mathrm{mol} / \mathrm{kg}$ (Fig. 1; Van Rooij et al., 2013).

\section{Material and methods}

This study was performed on two gravity cores (TTR17-396G and TTR17-399G) obtained during the Training Through Research TTR17 cruise in June 2008 on RV Professor Logatchev in the MMF in the eastern Alboran Sea (Fig. 1). Gravity core TTR17-396G is a $355 \mathrm{~cm}$ long sediment core and has been obtained from a water depth of $300 \mathrm{~m}$ at GPS coordinates $35^{\circ} 26,421^{\prime}$ (Lat. ${ }^{\circ} \mathrm{N}$ ), $02^{\circ} 31,077^{\prime}$ (Long. ${ }^{\circ} \mathrm{W}$ ). Gravity core TTR17-399G is a $340 \mathrm{~cm}$ long sediment core and was obtained at a water depth of $258 \mathrm{~m}$ at GPS coordinates $35^{\circ} 20,904^{\prime}$ (Lat. ${ }^{\circ} \mathrm{N}$ ), $02^{\circ} 32,178^{\prime}$ (Long. ${ }^{\circ} \mathrm{W}$ ).

Water parameters (e.g., temperature, salinity and dissolved oxygen) have been measured continuously throughout the water column with a CTD cast southeast of "Brittlestar Ridge 1" (Fig. 1) until a maximum water depth of $372 \mathrm{~m}$ (Van Rooij et al., 2013).

The gravity cores were sampled at a $20 \mathrm{~cm}$ interval for geochemical and micropaleontological investigations. Samples were processed following standard procedures for foraminiferal preparation (Spezzaferri and Coric, 2001). Approximately $10 \mathrm{~g}$ of dry bulk sediment per sample was washed through three mesh sieves $(63,125$ and $250 \mu \mathrm{m})$ and at least 200 specimens from the fractions 125 and $250 \mu \mathrm{m}$ were counted and glued on plummer-cells for archives. If the residue contained more than the target number of 300 benthic foraminifera in a single fraction, its volume was split with a dry splitter. If the residue contained $<300$ specimens, all specimens were counted. Taxonomic identification of foraminifera follows Cimerman and Langer (1991), Margreth (2010) and Spezzaferri et al. (2015). In order to make our benthic foraminiferal compositional dataset comparable to other datasets from the Mediterranean Sea (e.g., Caralp, 1988; Milker et al., 2009; Milker and Schmiedl, 2012) we decided to focus on the benthic foraminifera larger than $125 \mu \mathrm{m}$ (Appendix 1). The planktic foraminifera were identified on the fraction $>250 \mu \mathrm{m}$ (Appendix 2) in order to avoid overestimation due to the redeposition of smaller specimens (Lutze and Coulbourn, 1984).

Quantitative analyses of benthic foraminifera were performed with the Software PRIMER 6 (Clarke and Warwick, 2001). The diversity indices Shannon-Wiener $\left(H^{\prime}\right)$ and Fisher alpha were obtained using the same software (Clarke and Gorley, 2006). Non-metric and multidimensional scaling (nMDS) and hierarchical dendrogram analysis based on the Bray-Curties Similarity matrix was applied on the dataset of benthic foraminifera (Appendix 1). Results obtained from this multivariate statistical treatment provide useful information about possible and discrete distribution patterns of foraminiferal assemblages in sediment cores, including the contribution of each single species to the total similarity (Clarke and Warwick, 1994). To simplify the interpretation and reduce the number of species with very low contributions without losing significant information, a cut off value of the cumulative contribution was fixed at $90 \%$. A similarity cut is applied at different similarity levels according to the interpretation of the assemblages made with the abundance curves and with the lithology (Figs. 2 and 3).

The sediment fraction $>1 \mathrm{~mm}$ of the gravity cores was further investigated in order to carry out quantitative and taxonomic analysis of scleractinians and to analyze the most common carbonate macrofaunal groups (Appendix 3). All recognizable entire specimens and skeletal 
TTR17-399G

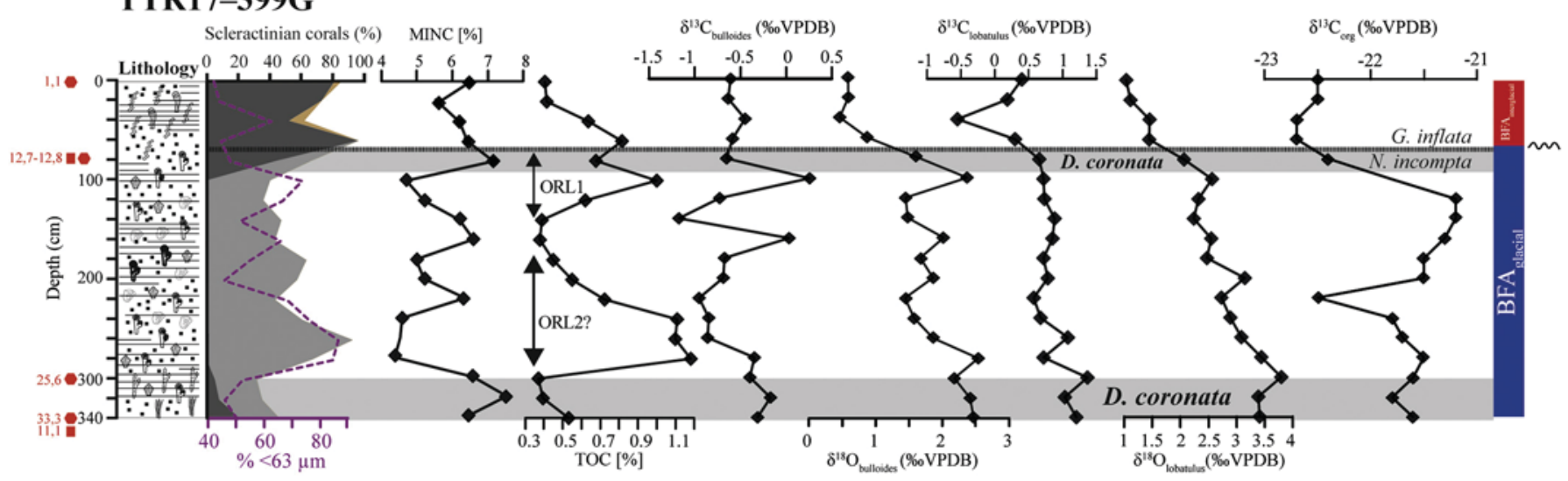

TTR17-396G

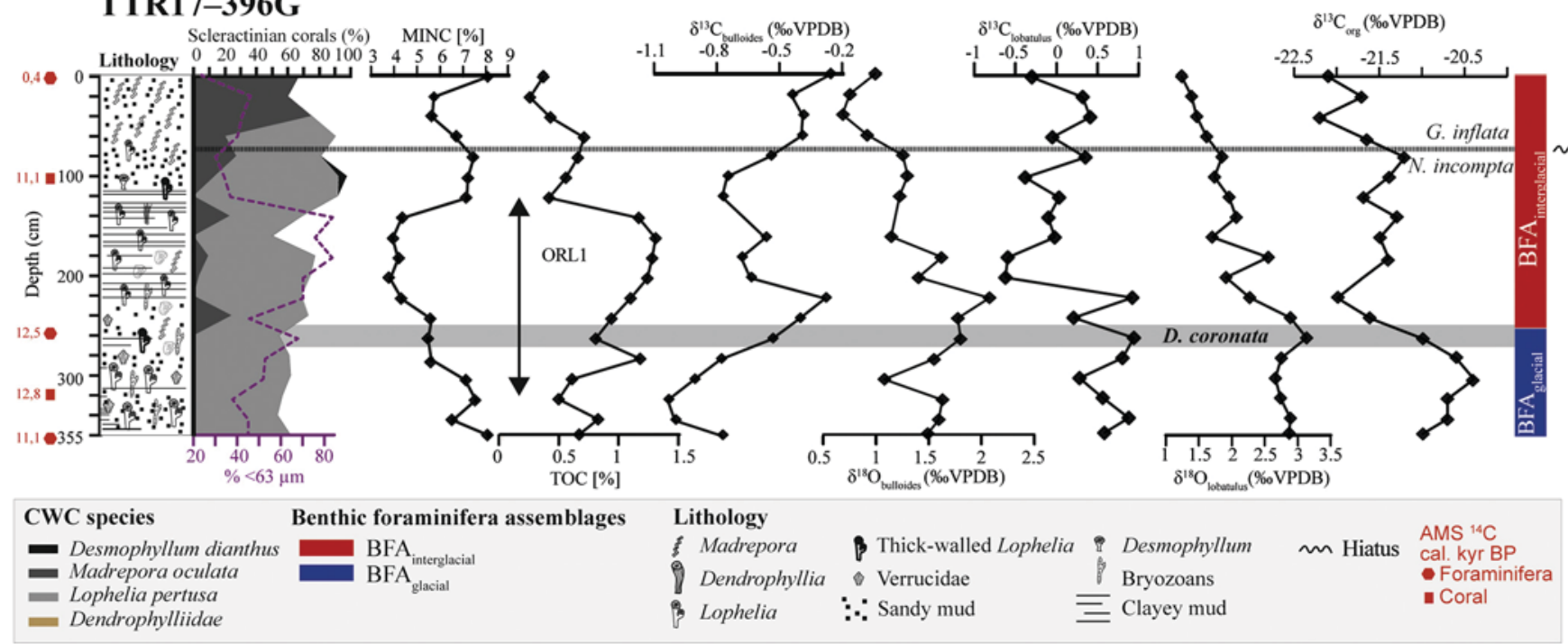

Fig. 2. Lithology of the studied cores including distribution of CWC taxa along the two studied cores based on quantitative analyses versus grain-size, mineral carbon (MINC), total organic carbon (TOC), planktic (Globigerina bulloides) $\delta^{13} \mathrm{C}$, benthic (Cibicides lobatulus) $\delta^{13} \mathrm{C}$ and $\delta^{18} \mathrm{O}$ and $\delta^{13} \mathrm{C}_{\text {org }}$ of sedimentary organic matter. The benthic foraminiferal assemblages (BFA), possible hiatuses along the cores and the distribution of benthic foraminifera Discanomalina coronata are also displayed. The dotted line marks the planktic foraminiferal turnover (Rohling et al., 1995).

fragments of scleractinian corals were counted and identified to the lowest possible taxonomic level (genus or species).

Radiocarbon dating was performed at the Eidgenössische Technische Hochschule (ETH) Zürich using the accelerator mass spectrometry (AMS) technique. Table 1 reports the dated samples, corrected and calibrated $(\mathrm{BP}=1950 \mathrm{CE})$. From selected samples, benthic foraminifera were picked until at least $5-10 \mathrm{mg}$ of pure carbonate were obtained. The species Discanomalina coronata, which lives attached to a hard substrate and associated to the CWC ecosystems (Margreth et al., 2009) was chosen whenever possible. Alternatively, the epibenthic foraminifera Cibicides lobatulus was picked. Both species were picked from the $>250 \mu \mathrm{m}$ sediment fraction. Due to the small amount of epibenthic foraminifera in gravity core TTR17-396G, it was decided to select only planktic foraminifera. The following species were picked from the $>125 \mu \mathrm{m}$ sediment fraction: Neogloboquadrina incompta, Globigerina bulloides and Globorotalia inflata. Specimens were cleaned in ultrasounds to remove eventual contamination. Coral fragments (25-50 mg) used for radiocarbon dating were selected according to their preservation and further treated by standard chemical leaching procedures. Table 2 summarizes the CWC species used for the AMS ${ }^{14} \mathrm{C}$ dating. A reservoir age correction of 400 years and the radiocarbon conventional ages were converted to calendar years (cal. years BP; $P=1950 \mathrm{CE}$ ) using the marine calibration curve Marine13 (Reimer et al., 2013) and the program OxCalV4.2.4 (Bronk Ramsey et al., 2013).
All ages are given in kiloyears before present (ka BP).

The stable isotope analyses were performed at the Stable Isotopes Laboratory of Institute of Earth Surface Dynamics of the University of Lausanne. Carbon and oxygen stable isotope composition of benthic ( $C$. lobatulus) and planktic (Globigerina bulloides) foraminifera (Table 2) were determined with the Thermo Fisher Scientific (Bremen, Germany) carbonate preparation device and GasBench II connected to a Delta Plus $\mathrm{XL}$ isotope ratio mass spectrometer (IRMS). Between 5 and 15 specimens of each species were picked in the $>250 \mu \mathrm{m}$ and cleaned twice in an ultrasonic bath. For G. bulloides, additional bulk material was washed in order to complete the samples. The stable carbon and oxygen isotope ratios ( $\delta^{13} \mathrm{C}$ and $\delta^{18} \mathrm{O}$ values) are reported in the delta $(\delta)$ notation as the per mil (\%) deviation relative to the Vienna Pee Dee Belemnite standard (VPDB). The standardization of the $\delta^{13} \mathrm{C}$ and $\delta^{18} \mathrm{O}$ values relative to the VPDB scale was done by calibration of the reference gases and working standards with IAEA standards. Analytical uncertainty $(1 \sigma)$, monitored by replicate analyses of the international calcite standard NBS-19 and the laboratory standards Carrara Marble was not greater than $\pm 0.05 \%$ for $\delta^{13} \mathrm{C}$ and $\pm 0.1 \%$ for $\delta^{18} \mathrm{O}$. The stable carbon isotope compositions $\left(\delta^{13} \mathrm{C}_{\text {org }}\right)$ of the organic fraction separated by acid treatment $(10 \% \mathrm{HCl})$ of the sediment samples were obtained by continuous flow elemental analyzer/isotope ratio mass spectrometry (EA/IRMS), using flash combustion on a Carlo Erba 1108 elemental analyzer (Fisons Instruments, Milan, Italy) connected via a 

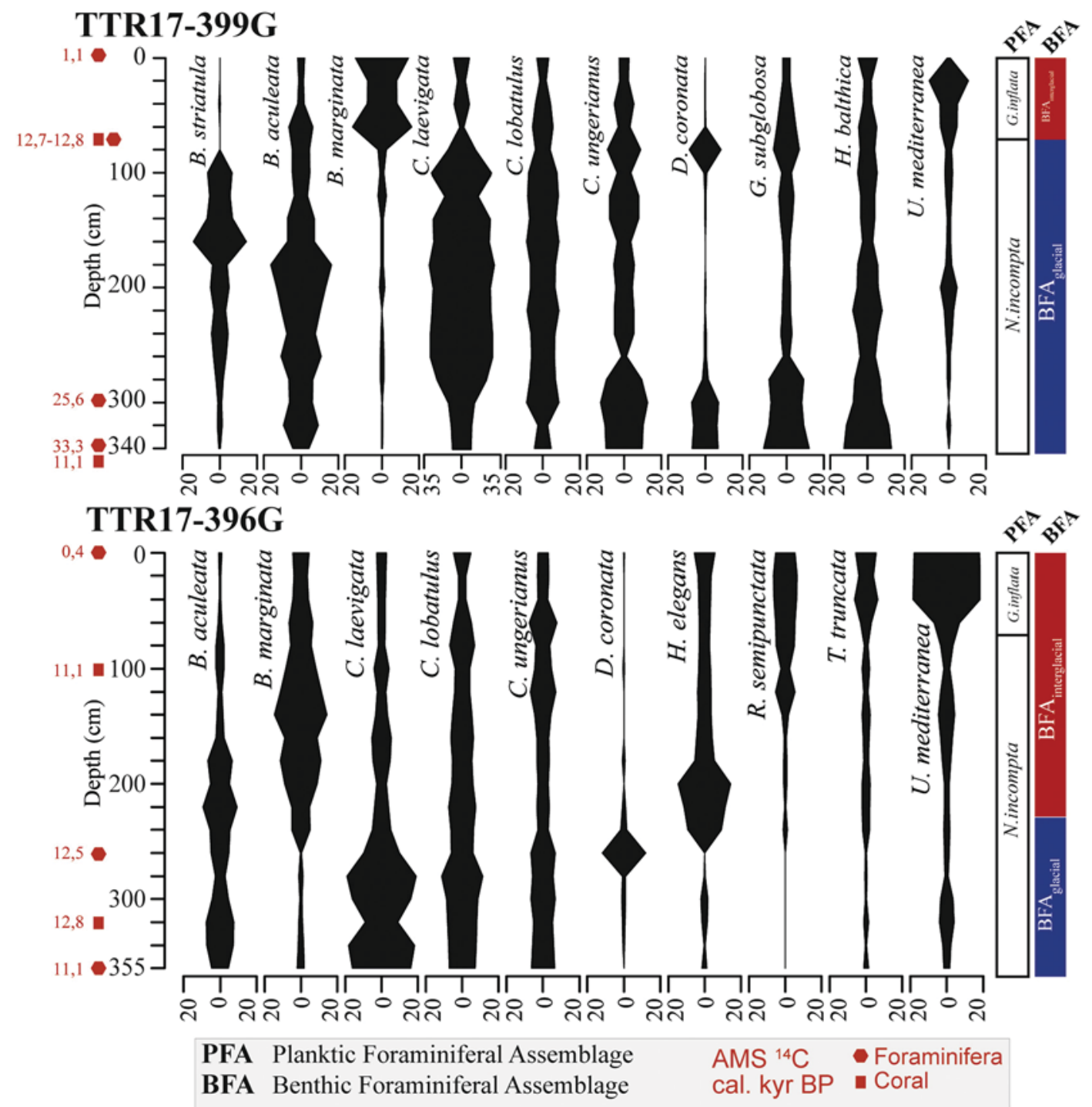

Fig. 3. Distribution (in \% of total fauna) of major benthic foraminifera in cores TTR17-396G and 399G including radiocarbon dating, planktic foraminiferal turnover (Rohling et al., 1995) and benthic foraminiferal assemblages (BFA).

Table 1

Radiocarbon $\mathrm{AMS}^{14} \mathrm{C}$ of sediment (benthic and planktic foraminifera) and cold-water coral fragments obtained from gravity cores TTR17-396G and TTR17-399G. Note that a reservoir correction of 400 years has been applied to all given dates.

\begin{tabular}{|c|c|c|c|c|c|c|c|}
\hline Core & $\begin{array}{l}\text { Core depth } \\
\text { (cm) }\end{array}$ & Material & Sample ID \# & $\begin{array}{l}\text { 14C-age } \\
\text { (years) }\end{array}$ & $\begin{array}{l}1 \sigma \text { error } \\
( \pm \text { years })\end{array}$ & $\begin{array}{l}2 \sigma \text { range cal. age } \\
\text { (years BP, } P=\text { AD 1950) }\end{array}$ & $\begin{array}{l}\text { Median probability age } \\
\text { (years BP) }\end{array}$ \\
\hline TTR17-399 G & 0 & Fo-Lobatula & ETH-55628 & 1559 & 27 & $1014-1214$ & 1127 \\
\hline TTR17-399 G & 80 & CWC-Lo & ETH-57684 & 11352 & 43 & $10859-14741$ & 12800 \\
\hline TTR17-399 G & 80 & Fo-Epibenthic & ETH-81125 & 11286 & 28 & $12800-12688$ & 12744 \\
\hline TTR17-399 G & 300 & Fo-Epibenthic & ETH-81126 & 21713 & 46 & $25742-25587$ & 25664 \\
\hline TTR17-399 G & 340 & Fo-Coronata & ETH-55629 & 29604 & 242 & $32829-33882$ & 33355 \\
\hline TTR17-399 G & 340 & CWC-Lo & ETH-57685 & 10073 & 40 & $11153-11032$ & 11092 \\
\hline TTR17-396 G & 0 & Fo-Planktonic & ETH-81129 & 850 & 21 & $517-439$ & 478 \\
\hline TTR17-396 G & 100 & CWC-Lo & ETH-81127 & 10080 & 27 & $11151-11051$ & 11101 \\
\hline TTR17-396 G & 260 & Fo-Planktonic & ETH-81130 & 10983 & 27 & $12596-12512$ & 12554 \\
\hline TTR17-396 G & 320 & CWC-Lo & ETH-81128 & 11350 & 28 & $12867-12743$ & 12805 \\
\hline TTR17-396 G & 355 & Fo-Planktonic & ETH-81131 & 10059 & 27 & $11137-11027$ & 11082 \\
\hline
\end{tabular}

Fo = Foraminifera; CWC = Cold-water corals, Mo=Madrepora oculata, Lo=Lophelia pertusa.

ConFlo III open split interface to a Delta V Plus isotope ratio mass spectrometer (Thermo Fisher Scientific, Bremen, Germany). The standard for carbon is Vienna Pee Dee Belemnite (VPDB). The calibration and assessment of the reproducibility and accuracy of the isotopic analysis was based on replicate analyses of international reference materials. Reproducibility and accuracy were better than $\pm 0.1 \%$ for $\delta^{13} \mathrm{C}_{\text {org }}$.

Total organic carbon content (TOC, in wt $\%$ ) was determined at the laboratory of Sediment Geochemistry of the Institute of Earth Sciences of the University of Lausanne on about $100 \mathrm{mg}$ bulk sediment using the 


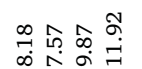

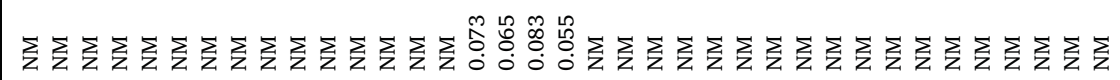

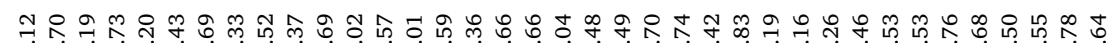

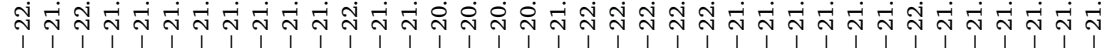

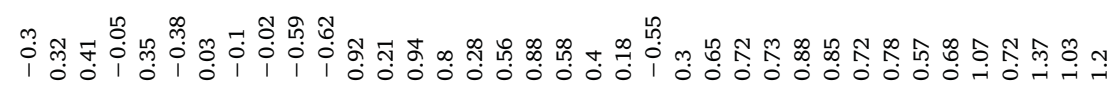

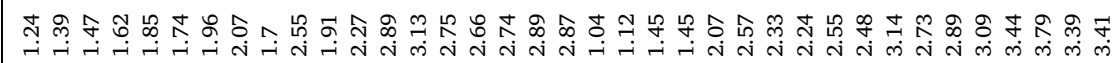

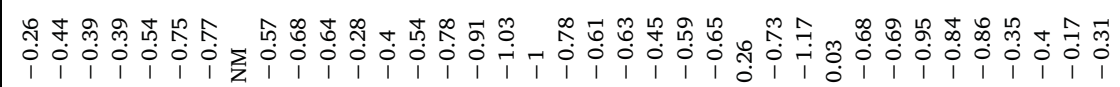

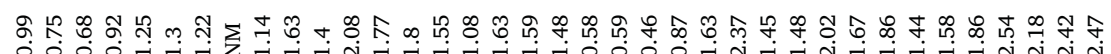

m กิ

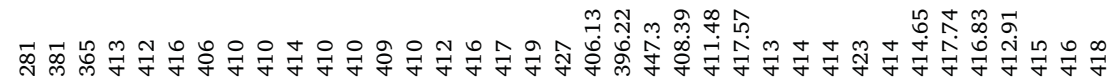

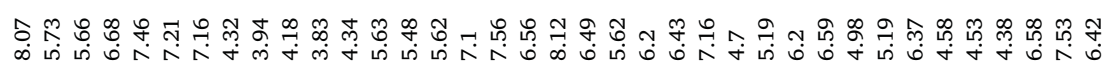

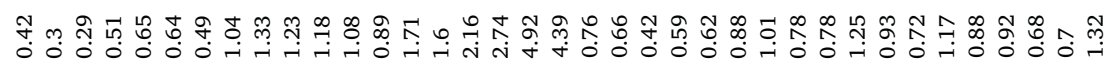

Э 웜용

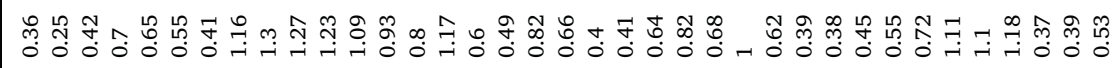

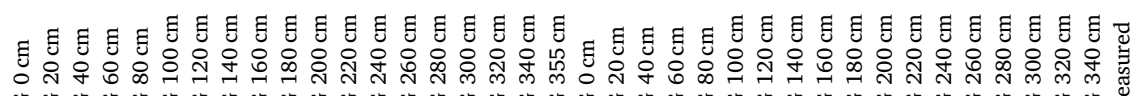

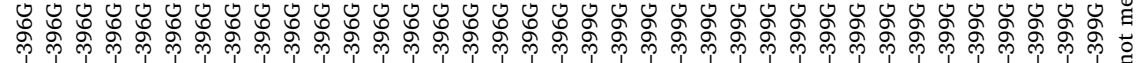

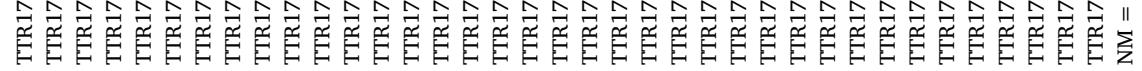


TTR17-396G \& TTR17-399G

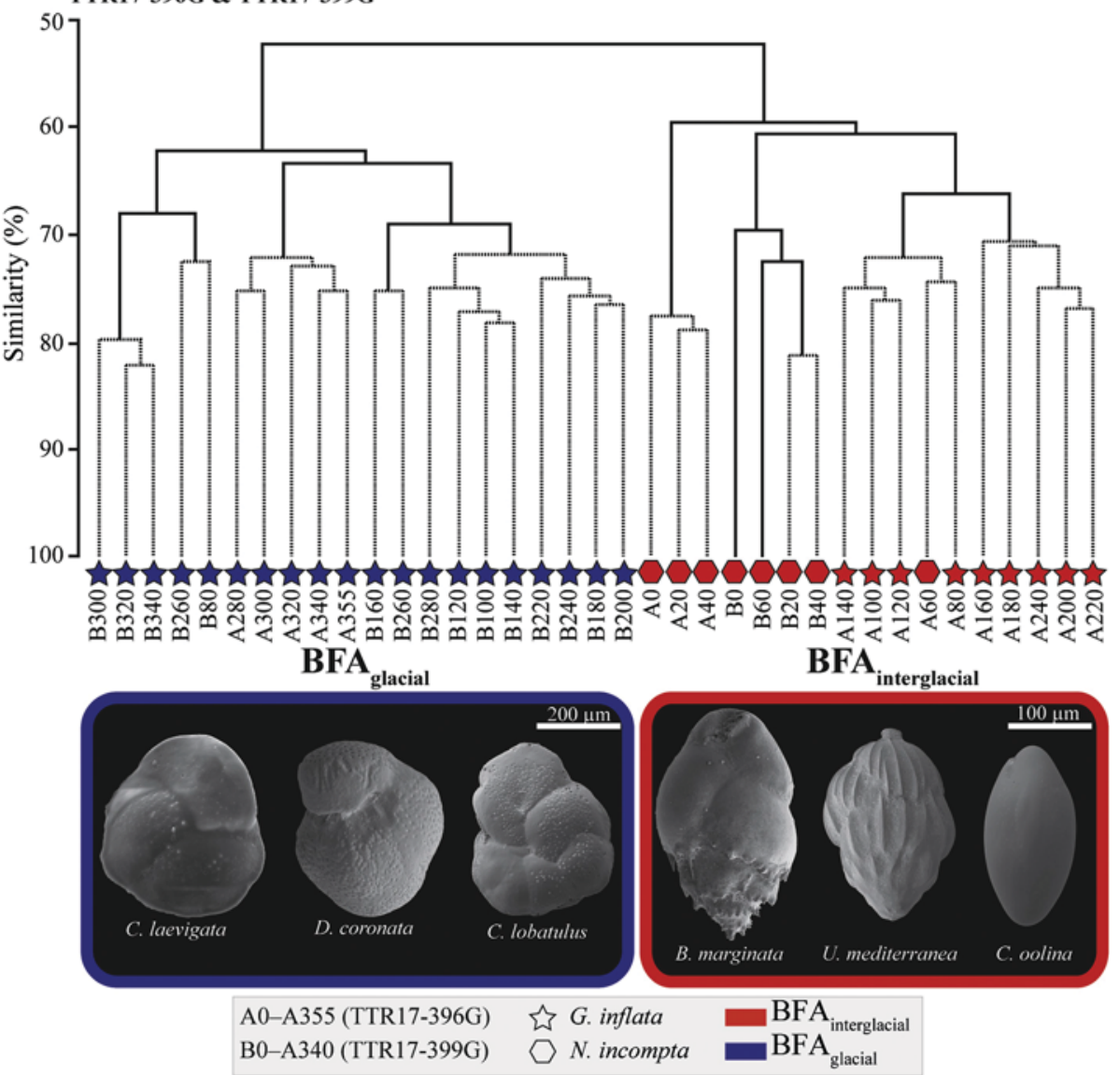

Fig. 4. Hierarchical dendrogram based on the BrayCurtis Similarity matrix of benthic foraminiferal compositional data of the studied cores. Two assemblages are separated at $52,4 \%$ of the Bray-Curties Similarity: $\mathrm{BFA}_{\text {glacial }}$ and $\mathrm{BFA}_{\text {interglacial. }}$ The illustrated benthic foraminifera are characteristic faunal components of the assemblages.
Rock-Eval6 technology and following the standard rock pyrolysis (Espitalié et al., 1986; Behar et al., 2001): the Hydrogen Index (HI), expressed in mg HC/g TOC, displays the total amount of pyrolyzed hydrocarbons resulting from the cracking of nonvolatile organic matter $(\mathrm{HI}=\mathrm{S} 2 \times 100 / \mathrm{TOC})$ and the Oxygen Index (OI, in $\mathrm{mg} \mathrm{CO} / \mathrm{g}$ TOC) which accounts for the amount of $\mathrm{CO}_{2}$ generated during the pyrolysis of the kerogen (OI=S3x100/TOC), both normalized to TOC. The Mineral Carbon (MINC) represents the percent of carbon derived from inorganic sources. The results of Rock-Eval analysis are given in Table 2 .

\section{Results}

\subsection{Lithology and distribution of CWCs}

The sediment cores TTR17-396G and TTR17-399G consist of an alternation of clayey to sandy mud with intercalation of CWC fragments up to $10 \mathrm{~cm}$ in diameter and other macrofaunal components such as e.g., bryozoans and verrucidae (Fig. 2; Appendix 3).

The distribution of CWC fragments follows a similar pattern in both cores with an interval dominated by Lophelia pertusa and successively replaced by Madrepora oculata towards the top of the cores (Fig. 2). In core TTR17-396G, first fragments of M. oculata were found at $260 \mathrm{~cm}$ whereas in cores TTR17-399G they occurred already at the base together with fragments of L. pertusa. However, the number of $M$. oculata fragments decreased and disappeared at $300 \mathrm{~cm}$ (Fig. 2).

A few fragments of Dendrophyllia spp. and Dendrophyllia dianthus were also found in the upper part of the cores (Fig. 2). Verrucidae sp. 1 occurs only in the lower part of the cores corresponding to the interval dominated by $N$. incompta (Fig. 3).

\subsection{Benthic foraminiferal distribution}

A total of 202 benthic foraminifera species belonging to 114 genera were identified in the two sediment cores recovered from the MMF (Appendix 1). Among these species, a relatively important part consists of species, which occurred only sporadically and at very low abundances (Appendix 2). They are usually characterized by small and/or fragile tests such as e.g., Favulina spp., Fissurina spp., Globulina spp., Homalohedra spp., Lagena spp., Lagenosolenia spp., Oolina spp., that have a poor preservation potential in the sediment records and will therefore not be discussed here further.

The distribution of the ten most frequent and abundant species is given in Fig. 3. Among these species, Cassidulina laevigata, Cibicides lobatulus and Cibicides ungerianus are the most frequent and abundant species accounting up to $30.2 \%, 11.2 \%$ and $12.6 \%$ to the total benthic foraminifera fauna, respectively. These species show a similar distribution with decreasing relative abundances towards the top of the cores (Fig. 3). Another important taxon is Bulimina marginata, which has a scarce distribution in the lower part of the cores and becomes abundant from $240 \mathrm{~cm}$ in core TTR17-396G and $60 \mathrm{~cm}$ in TTR17-399G (Fig. 3). The infaunal Bulimina aculeata has interestingly an opposite distribution pattern with higher abundances in the lower part of both cores contributing up to $16.3 \%$ to the total fauna.

The epiphytic dweller Discanomalina coronata is an important taxon in both cores contributing up to $11.9 \%$ to the total fauna. Discanomalina coronata occurs only at $260 \mathrm{~cm}$ in TTR17-396G and from 340 to $300 \mathrm{~cm}$ and at $80 \mathrm{~cm}$ in TTR17-399G (Figs. 2 and 3). This species has been associated with CWC settings by Margreth et al. (2009) and occurs where other epiphytic species such as Cibicidoides pachyderma and Rosalina bradyi are usually abundant (Appendix 1).

Other epiphytic species such as Hyalinea balthica, Rosalina 


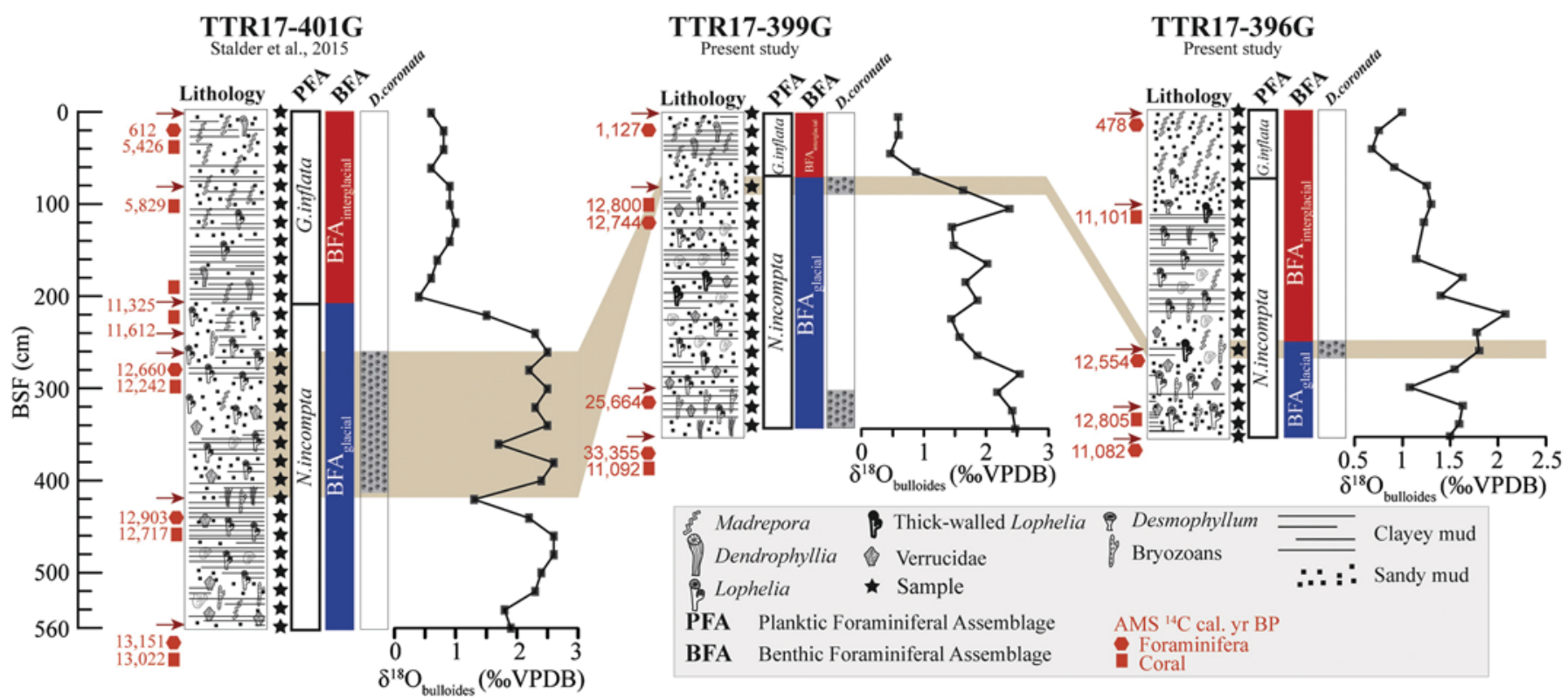

Fig. 5. Stratigraphic correlation between the studied cores (TTR17-396G, TTR17-399G) and core TTR17-401G (Stalder et al., 2015) based on lithology, AMS ${ }^{14} \mathrm{C}$ dating, distribution of selected macrofaunal components, distribution of benthic foraminifera Discanomalina coronata, planktic foraminiferal assemblages (PFA) and planktic $\delta^{18} \mathrm{O}$ (Globigerina bulloides).

semipunctata and Textularia truncata are periodically important benthic faunal components in specific intervals: $H$. balthica between 300 and 340 in core TTR17-399G (up to $12.8 \%$ ), T. truncata between 0 and $60 \mathrm{~cm}$ in core TTR17-396G (up to 5.6\%) and $R$. semipunctata between 0 and $120 \mathrm{~cm}$ in TTR17-396G (up to 6.5\%) (Fig. 3).

Additional important taxa are shallow infaunal species such as Bolivinella striatula, Hoeglundina elegans, Globocassidulina subglobosa and Uvigerina mediterranea (Fig. 3). Among those species, U. mediterranea becomes a dominant species in the uppermost part of both cores (up to 18.3\%). Globocassidulina subglobosa accounts in core TTR17-399G up to 12.2 and displays a similar distribution pattern with highest abundance in the lower core section (Fig. 3).

Bolivinella striatula is relatively abundant in TTR17-399G in the interval $100-340 \mathrm{~cm}$ (up to $14.2 \%$ ) and becomes successively rare in the upper core section.

Hoeglundina elegans is a relatively high contributor to the total fauna in core TTR17-396G. Hoeglundina elegans is rare in the interval $240-355 \mathrm{~cm}$, increases to a maximum of $9.2 \%$ at $200 \mathrm{~cm}$ and becomes relatively constant in the upper part of the core.

\subsection{Benthic foraminiferal assemblages (BFA)}

The hierarchical cluster analysis (Fig. 4) shows two high-level assemblages $\mathrm{BFA}_{\text {glacial }}$ and $\mathrm{BFA}_{\text {interglacial }}$ separated at $52.4 \%$ of the BrayCurties Similarity. $\mathrm{BFA}_{\text {glacial }}$ and $\mathrm{BFA}_{\text {interglacial }}$ characterize the benthic foraminiferal records in cores TTR17-396G and 399G (Fig. 4). The shift from $\mathrm{BFA}_{\text {glacial }}$ to $\mathrm{BFA}_{\text {interglacial }}$ coincides with a prominent decrease towards interglacial planktic and benthic $\delta^{18} \mathrm{O}$ values (Fig. 2) and thus indicates the transition to the Holocene. BFA glacial groups the samples from the lower part of the cores and is dominated by $C$. laevigata together with C. lobatulus, C. ungerianus, B. aculeata and G. subglobosa (Fig. 4; Appendix 1). The upper part of the cores is dominated by assemblage $\mathrm{BFA}_{\text {interglacial }}$ characterized by $B$. marginata with major accessory species $C$. lobatulus, $B$. aculeata, $C$. laevigata and $U$. mediterranea (Fig. 4; Appendix 2). The transition from the sediment interval corresponding to $\mathrm{BFA}_{\text {glacial }}$ to $\mathrm{BFA}_{\text {interglacial }}$ does occur at different core depths, namely $240 \mathrm{~cm}$ in core TTR17-396G and $60 \mathrm{~cm}$ in core TTR17399G (Fig. 2).

\subsection{Total organic carbon and stable isotopes}

The Total Organic Carbon (TOC) values range in both cores from $0.3 \%$ to $1.3 \mathrm{wt} \%$ (Fig. 2). The TOC curves display a clear pattern in core TTR17-396G with increased values in the interval $140-260 \mathrm{~cm}$ and in core TTR17-399G where two positive peaks occur at $180-200 \mathrm{~cm}$ $(0.72 \%)$ and $20-140 \mathrm{~cm}(1 \%)$ (Fig. 2). The TOC values show generally a positive correlation to the mud fraction (Fig. 2). The Mineral carbon (MINC) has values comprised between 3.8 and $8.1 \mathrm{wt} \%$ in TTR17-396G and 4.7 and $7.5 \mathrm{wt} \%$ in TTR17-399G and displays an opposite trend to the TOC values (Fig. 2).

The stable carbon isotope compositions $\left(\delta^{13} \mathrm{C}_{\text {org }}\right)$ of the organic fraction displays values ranging from $-20,36$ to $22,74 \%$ (Fig. 2; Table 2). For both cores, $\delta^{13} \mathrm{C}_{\text {org }}$ values are clearly higher in the period corresponding to $\mathrm{BFA}_{\text {glacial }}$ than $\mathrm{BFA}_{\text {interglacial }}$ (Fig. 2). The $\delta^{13} \mathrm{C}_{\text {org }}$ values from the interval $80-240 \mathrm{~cm}$ of core TTR17-396G show further evidence for decreased $\delta^{13} \mathrm{C}_{\text {org }}$ in the period dominated by $G$. inflata compared to $N$. incompta (Fig. 2; Appendix 2).

For core TTR17-396G the benthic $\delta^{13} \mathrm{C}$ values have a similar distribution pattern as the $\delta^{18} \mathrm{O}$ (Fig. 2). For core TTR17-396G the benthic $\delta^{13} \mathrm{C}$ values increase from $200 \mathrm{~cm}$ to the top whereas the $\delta^{18} \mathrm{O}$ decrease (Fig. 2). Values of benthic $\delta^{13} \mathrm{C}$ and $\delta^{18} \mathrm{O}$ are clearly higher in the period corresponding to $\mathrm{BFA}_{\text {glacial }}$ than $\mathrm{BFA}_{\text {interglacial }}$ The benthic $\delta^{18} \mathrm{O}$ values range from 0.9 to $3.8 \%$ and decrease in all cores towards the top. The topmost samples have a benthic $\delta^{18} \mathrm{O}$ value of $1.2 \%$ for core TTR17-396G and 1.0\%o for TTR17-399G (Fig. 2; Table 2). The benthic $\delta^{13} \mathrm{C}$ values ranged between -0.6 and $1.4 \%$ and display large negative excursions at $200 \mathrm{~cm}(-1.5 \%)$ in core TTR17-396G and at $40 \mathrm{~cm}$ ( $-0.8 \%$ ) in TTR17-399G (Fig. 2; Table 2).

The benthic $\delta^{18} \mathrm{O}$ curves display generally a similar evolution as the planktic $\delta^{18} \mathrm{O}$ with isotopic values typical of the last late glacial period recorded in the Mediterranean Sea for the interval corresponding to $\mathrm{BFA}_{\text {glacial }}$ and the Holocene for $\mathrm{BFA}_{\text {interglacial }}$ (Fig. 2). The planktic $\delta^{13} \mathrm{C}$ curves follow an evolution similar to the planktic $\delta^{18} \mathrm{O}$ curves with values ranging from -1.17 to $0.26 \%$. The planktic $\delta^{13} \mathrm{C}$ signal of core TTR17-396G shows a similar signal than the benthic one with decreased values in the interval 80 and $220 \mathrm{~cm}$ (Fig. 2). 


\subsection{Chronology}

The chronology of cores TTR17-396 and 399G is constraint by 11 AMS ${ }^{14} \mathrm{C}$ dating ( 4 on CWC fragments and 7 on foraminifera), the distribution of planktic (PFA) and benthic foraminiferal (BFA) assemblages, sediment samples characterized by the occurrence of Discanomalina coronata as well as planktic $\delta^{18} \mathrm{O}$ data (Fig. 2; Tables 1 and 2). In order to refine the chronology of the two sediment cores, a stratigraphic correlation with sediment core TTR17-401G recovered in the same area and spanning the time period 0.6-13,1 ka BP (Stalder et al., 2015) is proposed in Fig. 5. Radiocarbon dating, lithology, distribution of PFA and BFA as well as the planktic $\delta^{18} \mathrm{O}$ data of core TTR17-401G have been published in Stalder et al. (2015).

The radiocarbon dating reveals that core TTR17-399G spans the time interval 1.1-33.3 ka BP and thus reaching back to Marine Isotope Stage MIS3. Core TTR17-396G covers the time span 0.5-12.5 ka BP. The age of $11 \mathrm{ka}$ BP obtained at the base of this core is not in chronological order with the ages from the upper sediments. The inverted ages point to redistribution or bioturbation of sediments within this interval. This is also supported by the decreased planktic $\delta^{18} \mathrm{O}$ values displayed in this interval (Fig. 5). Thus, we keep the oldest age of $12.5 \mathrm{ka}$ BP obtained for this core as the lower age limit of the record.

The dated CWC fragments yield ages ranging from $11.1 \mathrm{ka}$ BP at $340 \mathrm{~cm}$ to $12.7 \mathrm{ka}$ at $80 \mathrm{~cm}$ core deth in core TTR17-399G and from $12.8 \mathrm{ka} \mathrm{BP}$ at $355 \mathrm{~cm}$ to $11.1 \mathrm{ka} \mathrm{BP}$ at $100 \mathrm{~cm}$ core depth in core TTR17-396G (Fig. 2; Table 1). These ages fall well within the age range obtained from radiocarbon dating of CWC fragments from the MMF (Fink et al., 2013; Stalder et al., 2015). With regard to the data from these two latter authors, CWC growth in the MMF did occur in the periods $12.2-13.5 \mathrm{ka} \mathrm{BP}, 9.8-11.6 \mathrm{ka} \mathrm{BP}$ and $5.4-5.8 \mathrm{ka} \mathrm{BP}$.

The distribution of planktic foraminifera in these two cores shows the occurrence of two major intervals, one dominated by Neogloboquadrina incompta and further replaced by a second interval dominated by Globorotalia inflata (Fig. 2; Appendix 2). This planktic foraminiferal turnover has been well described in the Alboran Sea by Rohling et al. (1995) and assumed to have occurred around 8 ka BP. The transition from the $N$. incompta dominated interval to $G$. inflata occurs at $60 \mathrm{~cm}$ core depth in both cores. In core TTR17-401G this transition occurs at a much deeper core depth (Fig. 5; Stalder et al., 2015).

Similarly, the transition from $\mathrm{BFA}_{\text {glacial }}$ to $\mathrm{BFA}_{\text {interglacial }}$ is neither recorded at the same core depths in cores TTR17-396G and 399G nor in TTR17-401G, thus probably involving important differences in sediment deposition, accumulation and/or preservation. The presence of large hiatuses in sediment records related to CWC settings is a common feature due to the prevailing enhanced hydrographical regime (López Correa et al., 2012).

This is further strongly suggested by the distribution of PFA and BFA in core TTR17- 396G where their respective transitions do not co-occur at the same core depth as in cores TTR17-399G and 401G (Fig. 5). The sediment interval $80-240 \mathrm{~cm}$ of core TTR17-396G has not been deposited or preserved in cores TTR17-399G and 401G. This is well in agreement with the highest planktic $\delta^{18} \mathrm{O}$ value of core TTR17-396G falling within the $\mathrm{BFA}_{\text {interglacial }}$ interval and not in $\mathrm{BFA}_{\text {glacial }}$ as it is the case for the two other cores (Fig. 5). The youngest transition from $\mathrm{BFA}_{\text {glacial }}$ to $\mathrm{BFA}_{\text {interglacial }}$ is dated at $12.5 \mathrm{ka} \mathrm{BP}$ in core TTR17-396G.

The best stratigraphic correlation obtained between the three cores is the sediment interval containing the epibenthic $D$. coronata (Fig. 5). This sediment interval is found at $260 \mathrm{~cm}$ core depth in core TTR17-396G and is dated at $12.5 \mathrm{ka} \mathrm{BP}$, at $80 \mathrm{~cm}$ in core TTR17-399G and dated at $12.7 \mathrm{ka} \mathrm{BP}$ and, between 260 and $420 \mathrm{~cm}$ in core TTR17$401 \mathrm{G}$ and characterized by an of 12.6-12.9 ka BP (Fig. 5; Stalder et al., 2015). Thus, the interval in which $D$. coronata occurs lasts at least from 12.5 to $12.9 \mathrm{ka}$ BP and corresponds well to the Younger-Dryas (Cacho et al., 2001, 2002; Combourieu Nebout et al., 2009).

\section{Discussion}

5.1. Benthic foraminiferal assemblages through time in the MMF: their (paleo-) environmental message

\subsubsection{BFA glacial: low stratified and nutrient-rich waters}

Fossil (dead) and live (stained) assemblages similar to $\mathrm{BFA}_{\text {glacial }}$ have been reported from CWC settings on the Norwegian shelf (Stalder et al., 2014; Spezzaferri et al., 2013), in the Porcupine Seabight and Rockall Trough (Rüggeberg et al., 2007; Margreth et al., 2009; Schönfeld et al., 2011; Smeulders et al., 2014) and from mud volcanoes in the Alboran Sea (Margreth et al., 2011) and were interpreted as indicative of elevated near-bottom currents, elevated nutrient and oxygen availability at the seafloor.

Benthic foraminiferal assemblages dominated by C. laevigata are generally documented along high primary productivity areas where elevated fluxes of labile organic matter reach the seafloor as e.g., from the West African continental margin (Schmiedl et al., 1997) and the Western Iberian continental shelf (Levy et al., 1995; Martins et al., 2006). Based on a sediment record from the Northern Cape Basin (SW Africa), Schmiedl and Mackensen (1997) noticed that C. laevigata flourished during glacial times in response to strongly seasonal and highly productive surface waters. From the northern Florida continental slope, Sen Gupta et al. (1981) reported an assemblage dominated by buliminids together with $C$. laevigata and $G$. subglobosa taking advantage of seasonal strong upwelling.

In the Mediterranean Sea, benthic foraminiferal assemblages dominated by $C$. laevigata are reported from shallow shelf to deep bathyal environments supplied by relatively fresh organic matter (De Stigter et al., 1998; De Rijk et al., 2000; Milker et al., 2009). Schmiedl et al. (1998) linked the dominance of C. laevigata in the benthic foraminiferal fauna of the Ionian Sea to enhanced $\mathrm{C}_{\text {org }}$ fluxes triggered by increased primary productivity during glacial times. Enhanced $\mathrm{C}_{\text {org }}$ fluxes during the interval corresponding to $\mathrm{BFA}_{\text {glacial }}$ is well corroborated by the high contribution of the opportunistic intermediate to deep infaunal B. aculeata and to larger extend G. subglobosa. Bulimina aculeata is one of the most opportunistic taxa in the Mediterranean Sea and is strongly dependent on organic matter content in the sediment (De Rijk et al., 2000). This species is able to feed on degraded organic matter and tolerates dysoxic conditions (e.g., Schmiedl et al., 2000; Caulle et al., 2014). Mojtahid et al. (2009) showed that B. aculeata proliferates in the vicinity of the Rhone River pro-delta where high terrestrial $C_{\text {org }}$ inputs cause oxygen depletion in the sediments. From in situ feeding experiments with ${ }^{13} \mathrm{C}$-labeled algae in the deep Sagami Bay (Japan), Nomaki et al. (2006) concluded that B. aculeata is a seasonal phytophagous species ingesting preferably fresh phytodetritus but is able to feed on refractory sedimentary organic matter when the productivity is reduced.

The distribution of the infaunal G. subglobosa has often been associated with environments characterized by the deposition of fresh phytodetrital aggregates on the seafloor after seasonal bloom events (e.g., Gooday, 1993, 1994; Fariduddin and Loubere, 1977; Suhr et al., 2003). This species is sensitive to oxygen content at the water-sediment interface and is usually reported from well-oxygenated and high-energy benthic environments (Mackensen et al., 1995; Milker et al., 2009).

This is well in agreement with the overall large contribution of the epibenthic species C. lobatulus and C. ungerianus and, compared to $\mathrm{BFA}_{\text {interglacial, }}$ the markedly higher abundances of other epibenthic dwellers such as e.g., C. pachyderma, Cibicides refulgens, D. coronata, Hanzawaia boueana, Rosalina brady, and Planulina ariminensis (Appendix 1). These species show high abundances in environments characterized by the availability of elevated substrates (e.g., coral branches, pebbles) under relatively strong hydrographic conditions and oxygen-rich bottom waters (Linke and Lutze, 1993; De Stigter et al., 1998; Margreth et al., 2009). Most of these species belong to the "epibenthic group" recognized by Schönfeld (1997) in the Gulf of Cadiz and associated with 
the Mediterranean Outflow Water (MOW), which provides elevated benthic habitats with food particles. Furthermore, in the North Atlantic and the North Sea, C. lobatulus and in particular C. ungerianus are characteristic for the mixed water assemblage, which takes over after seasonal stratification (Martins et al., 2006 and references therein). Increased current velocities at the boundary layer during $\mathrm{BFA}_{\text {glacial }}$ is also suggested by relatively high abundances of the infaunal Trifarina angulosa, which is able to withstand permanent winnowing (Schönfeld, 2002).

We thus conclude that $\mathrm{BFA}_{\text {glacial }}$ is representative of a benthic environment characterized by high quantity and quality organic matter in response to enhanced primary productivity and by generally low stratified water masses with elevated oxygen concentrations at the seafloor. Generally well-oxygenated bottom waters during $\mathrm{BFA}_{\text {glacial }}$ are also supported by the benthic $\delta^{13} \mathrm{C}$ (Fig. 2). During the late Pleistocene, relatively strong near-bottom currents have prevailed at the MMF preventing the benthic fauna from sediment smothering and critical $\mathrm{C}_{\text {org }}$ accumulation.

However, the relatively important contribution of opportunistic taxa such as e.g., Bolivina dilatata, Bolivina striatula, B. aculeata, and $N$. turgida and our geochemical data indicate that the oceanographic conditions during $\mathrm{BFA}_{\text {glacial }}$ were periodically rather unstable. This is well in agreement with the conclusions of Stalder et al. (2015) who showed evidence for variability in sea-surface salinity during the Alleröd interstadial due to enhanced Atlantic water inflow and continental runoff.

\subsection{2. $B F A_{\text {interglacial: }}$ stratified and oxygen-depleted bottom waters under} meso-eutrophic conditions

Assemblages dominated by buliminiids comparable to $\mathrm{BFA}_{\text {interglacial }}$ are found nowadays in the Adriatic Sea within the Po river-influenced clay belt (Jorissen, 1987; Van der Zwaan and Jorissen, 1991) where they are conducive of benthic environments enriched in food particles and periodically low oxygen content. The deep infaunal Bulimina marginata (Murray, 2006) has been found in the Adriatic Sea in environments characterized by fine-grained sediments enriched in $\mathrm{C}_{\text {org }}$ and periodic anoxic events at the water sediment interface (Donnici and Barbero, 2002). In the Gulf of North Evoikos (Aegean Sea), Drinia et al. (2014) concluded that benthic foraminiferal assemblages dominated by B. marginata were indicative of fluctuating bottom water masses triggered by increasing water depths and enhanced refractory organic matter at the seafloor and in the sediments. Bartels-Jónsdóttir et al. (2006) also demonstrated from the Tagus prodelta that B. marginata was found down to $10 \mathrm{~cm}$ into the sediments and was preferentially ingesting decaying refractory organic matter or bacterial stocks. According to Martins et al. (2006), the distribution of $B$. marginata is closely linked to high $\mathrm{C}_{\text {org }}$ fluxes to the seafloor and to fine-grained sediments and is generally a key indicator species for stratified water masses.

The contribution of $U$. mediterranea within $\mathrm{BFA}_{\text {interglacial }}$ corroborates the high food level in the sediments during this interval. Many authors (e.g., Lutze and Coulbourn, 1984; De Rijk et al., 2000; Fontanier et al., 2002) have reported the occurrence of this shallow infaunal species from benthic environments supplied by high fluxes of labile and easily metabolizable organic matter and under relatively well-oxygenated bottom waters. However, Koho et al. (2008) provided evidence for the ability of this species to adapt on low nutritional organic matter in $\mathrm{C}_{\text {org }}$-enriched areas. This is well in agreement with the findings of Schmiedl et al. (2010) who suggested that increasing abundances of $U$. mediterranea during the late Holocene in the Northern Aegean Basins was primarily linked to additional terrestrial organic matter inputs through extensive soil erosion. In the deep $(795 \mathrm{~m}) \mathrm{Al}$ boran Sea, Caralp (1988)) noticed an increase in $U$. mediterranea during the late Holocene and attributed this species to the presence of intermediate waters and to a slightly nutrient and oxygen diminished benthic environment. Geslin et al. (2004) mentioned from their aquaria

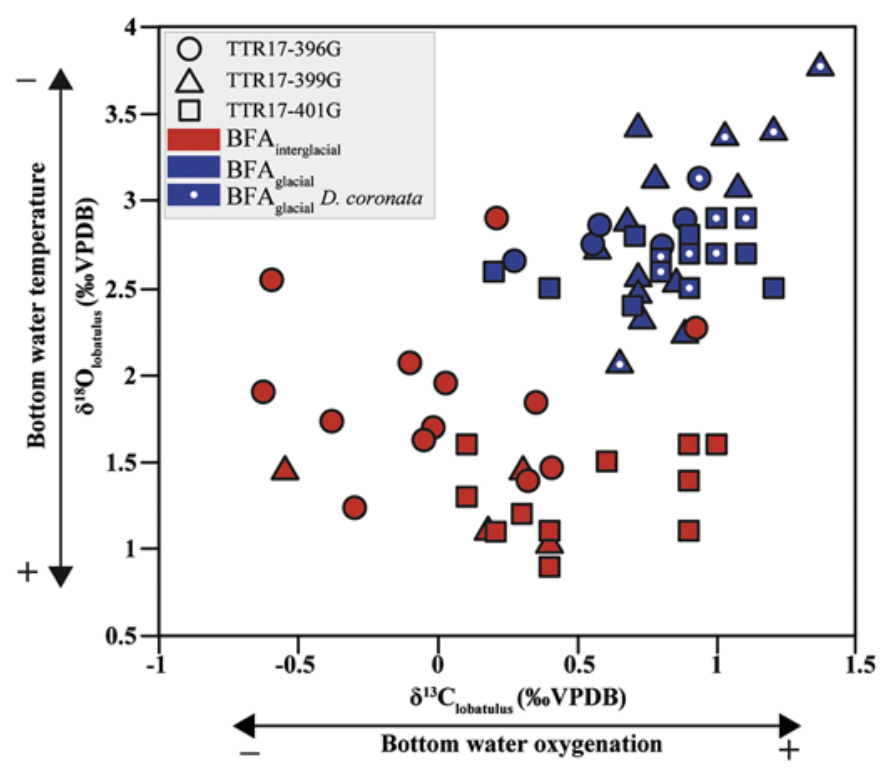

Fig. 6. Crossplot of benthic $\delta^{13} \mathrm{C}$ and $\delta^{18} \mathrm{O}$ data. Samples where Discanomalina coronata occurs are marked by a white dot.

experiments the capacity of this species to live under periodically decreased oxygen content.

Accordingly, we infer that $\mathrm{BFA}_{\text {interglacial }}$ is indicative of elevated organic matter accumulation on the seafloor and in the sediments through periodically decreased oxygen concentration and hydrographic energy in the benthic boundary layer. In comparison to $\mathrm{BFA}_{\text {glacial }}$, the bottom water masses were generally less ventilated as suggested by benthic $\delta^{13} \mathrm{C}$ (Fig. 6) and by the decrease in the epibenthic foraminifera. The development of associated benthic foraminifera such as e.g., Amphycorina scalaris, Bigenerina nodosaria, Bolivina alata, Bulimina striata, Chilostomella oolina, Globobulimina affinis, Gyroidina spp., Hoeglundina elegans and Lenticulina spp. during $\mathrm{BFA}_{\text {interglacial }}$ provide further evidence for $\mathrm{C}_{\text {org }}$-enrichment of the sediments and periodic decreased oxygen concentration at the seafloor (De Stigter et al., 1998; De Rijk et al., 2000; Schmiedl et al., 2000; Mojtahid et al., 2006; Drinia et al., 2007).

Furthermore, $\mathrm{BFA}_{\text {interglacial }}$ suggests that the water column was well stratified during the Holocene, which is in good agreement with the modern water mass configuration described by Rohling et al. (1995).

\subsection{Micro- versus macrofauna: what can foraminifera tell about CWCs?}

The shift in the benthic foraminiferal assemblage is also accompanied by a shift in the scleractinian community with increased abundances of Madrepora oculata and Dendrophyllia spp. during the Holocene (Fig. 2). In their review of CWCs in the Mediterranean Sea, Taviani et al. (2005) concluded with similar observations, namely a widespread distribution of L. pertusa during glacial times and isolated colonies during the Holocene. Similarly, Fink et al. (2015) concluded that $M$. oculata started to develop in the western Mediterranean during the early Holocene. The successive replacement of Lophelia pertusa, showing in some layers of the $\mathrm{BFA}_{\text {glacial }}$ a typical Atlantic thick-walled morphotype today absent in the modern Mediterranean (Malinverno et al., 2010; Vertino et al., 2014), by M. oculata and Dendrophyllia spp. can be attributed to a major change at the benthic boundary layer during the Late Pleistocene-Holocene transition in the eastern Alboran Sea including a warming of the bottom water masses, periodic decreases in the bottom water oxygenation and in the near-bottom current velocity. As inferred from the benthic foraminiferal assemblages, the MMF experienced a major change in the quantity and quality of the organic matter that reached the seafloor during the Holocene. 
Furthermore, the shift in the benthic foraminiferal assemblages strongly suggests that the $\mathrm{C}_{\text {org }}$-enrichment of the sediments was accompanied by a decrease in the energy at the water-sediment interface. The data from this study thus show evidence for a higher capacity or tolerance of $M$. oculata and Dendrophyllia spp. than L. pertusa to adapt on intensive environmental changes. This is well in agreement with the observations of Wienberg et al. (2009) from the adjacent Gulf of Cadiz where Dendrophylliids became dominant in the scleractinian community in relation to decreased oxygen content at the benthic boundary layer.

\subsection{Hiatuses: the recurrent problematic of CWC sediment records}

Cold-water coral settings are commonly associated with the occurrence of relatively strong bottom currents generated by complex seafloor morphology or internal hydrographic processes such as tidal and internal waves (e.g., Freiwald et al., 2004; Davies et al., 2009). Nearbottom currents of up to $44 \mathrm{~cm} / \mathrm{s}$ have been measured around CWC reefs (Eide, 1979). Dorschel et al. (2007) have provided evidence for preferential erosion of declining CWC structures weakened through bioerosion and physicochemical alteration. The consequent presence of hiatuses and disturbed age-depth relationships along sediment records has been reported from relatively shallow Norwegian fjords (López Correa et al., 2012) and deep-sea CWC environments off Ireland (Foubert et al., 2007; Rüggeberg et al., 2007; Frank et al., 2009; Titschack et al., 2009; Raddatz et al., 2011, 2014).

The presence of hiatuses along the cores recovered in the MMF is strongly suggested by geochemical proxies $\left(\delta^{13} \mathrm{C}\right.$ and $\left.\delta^{18} \mathrm{O}\right)$, grain-size distribution and verified by radiocarbon dating and planktic or benthic foraminiferal assemblages. The age reversal recorded at the base of cores TTR17-396G and 399G involves local sediment disturbation that can be explained by the following processes: 1) displacement of sediments and coral fragments along the core during the coring, 2) physical erosion of the reef structure by currents and redeposition of sediments and/or 3) collapse of the pre-existing coral-framework. With regard to the distribution of $\mathrm{BFA}_{\text {glacial }}$ and $\mathrm{BFA}_{\text {interglacial }}$ and their respective length in our cores, it appears obvious that major hiatuses or variation in the mean sedimentation rates did occur. In cores TTR17-399G and $401 \mathrm{G}$, the transition from $\mathrm{BFA}_{\text {glacial }}$ to $\mathrm{BFA}_{\text {interglacial }}$ is synchronous to the transition from the $N$. incompta dominated to the $G$. inflata dominated interval (Fig. 2). In core TTR17-396G the transition to the $G$. inflata interval occurs much later as suggested by the relatively important sediment thickness $(180 \mathrm{~cm})$. The faunal reversal in the planktic foraminifera occurred in the Alboran Sea around 7.6-8 ka BP (Rohling et al., 1995; Rohling and De Rijk, 1999; Margreth et al., 2011) with the onset of the modern oceanographic configuration. If so, the interval recorded in core TTR17-396G would likely represent the early Holocene, namely the time window comprised between the end of the YD and 7.6-8 ka BP overlapping with the African Humid Period (AHP = 14.8-5.5 ka BP; deMenocal et al., 2000). High-resolution deepsea records (e.g., Adkins et al., 2006; Combourieu Nebout et al., 2009; Fletcher et al., 2010) have shown that during the early Holocene the Mediterranean borderlands were characterized by wet conditions with verdant landscapes and well developed forest populations whereas reduced thermohaline circulation and deep-water renewal prevailed in the Mediterranean basins (Jiménez-Espejo et al., 2007; Schmiedl et al., 2010). This period coincides with the deposition of sapropel layer S1a (10.1-8.2 ka BP; Hennekam et al., 2014) in the eastern Mediterranean Sea which was mainly driven by permanent stratification due to decreased salinities at the surface waters and subsequent anoxic conditions in the deep basins (De Lange et al., 2008). The sustained monsoondriven rainfalls during the AHP on the northern African borderlands have presumably fuelled the Mediterranean Sea with continental nutrients and thus increased the marine primary productivity and contributed, in connection to deep-water anoxia, to the deposition of organic-rich sediments (Rossignol-Strick, 1985; Rohling, 1994). All geochemical proxies of core TTR17-396G strongly point to less

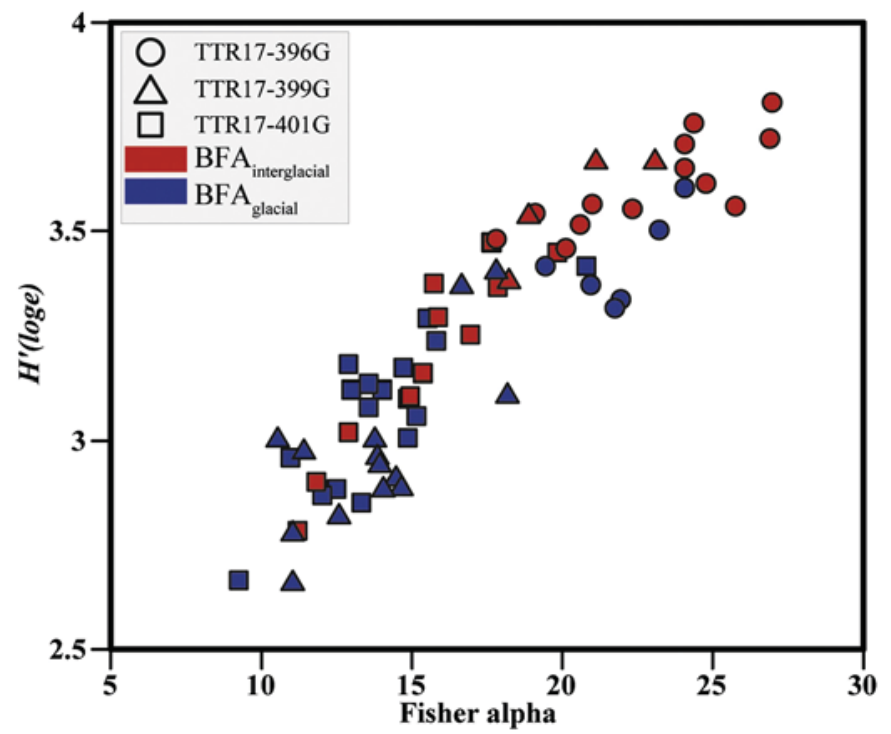

Fig. 7. Diversity of benthic foraminifera from the studied cores.

favourable ecological conditions at the benthic boundary layer during the early Holocene with a marked decrease in all planktic and benthic $\delta^{13} \mathrm{C}$ and $\delta^{18} \mathrm{O}$ (Fig. 2). The synchronous increase of TOC and finegrained sediments suggest that during this period the MMF experienced elevated $\mathrm{C}_{\text {org }}$ fluxes under enhanced continental river runoff conditions, which lead to $\mathrm{C}_{\text {org }}$-enrichment of the sediments in relation to low ventilated bottom waters and high sediment loads. This is well in agreement with the lowest MINC values reached during that time and the proliferation of $H$. elegans together with B. marginata and B. aculeata (Figs. 2 and 3). A change in the sedimentation pattern during the early Holocene has been documented over the whole Mediterranean Basin (e.g., Frigola et al., 2007; Hamann et al., 2008; Revel et al., 2014) with a general increase in the sediment load supplied to the shelf and deep basins by fluvial transport. This is also verified from the northern Moroccan coast close to the Cap Tres Forcas by extensive (20-25 m thick) alluvial deposits of fine-grained sediments from the lower Rharbian (early Holocene) found in the Wadi Kert valley (North-eastern Morocco; Fig. 1) (Barathon et al., 2000). McCullock et al. (2010) argued that CWCs started to decline in the Mediterranean Sea shortly after the post-YD CWC growth interval (10.9 ka BP) because of habitat loss related to rapid burial by sediment-rich meltwaters from the vanishing European glaciers.

We believe that the preservation of this interval in core TTR17-396G is related to greater water depth $(+\sim 50 \mathrm{~m})$ and its relatively large distance from the two other cores located closer to the Moroccan shoreline, resulting probably in a lower exposure to hydrographic energy and erosional processes (Fig. 1).

\subsection{Benthic foraminiferal diversity-D. coronata: indicators of stable benthic environments?}

The diversity of benthic foraminifera over the last $33.5 \mathrm{ka}$ was comparatively higher during the interglacial than the glacial interval (Fig. 7). Dead benthic foraminifera from $\mathrm{BFA}_{\text {interglacial display similar }}$ numbers of taxa and Shannon $\left(H^{\prime}\right)$ diversity indices as from the surrounding shelf environments (Milker et al., 2009; Milker and Schmiedl, 2012). The relative higher diversity during $\mathrm{BFA}_{\text {interglacial }}$ suggests that the benthic boundary layer conditions were less variable than during $\mathrm{BFA}_{\text {glacial }}$ probably in relation to greater water depth of the MMF during the Holocene ( $+60 \mathrm{~m}$; Lambeck et al., 2011). Furthermore, during interglacial times, opportunistic and specialized taxa such as e.g., A. scalaris, B. nodosaria, B. alata, B. striata, G. affinis, H. elegans, Lenticulina spp., $R$. elongastriata, $R$. semipunctata and Textularia spp. developed in 
the MMF, finding suitable microhabitats in an environment becoming globally more eutrophic, warmer and less turbulent.

Additional factors which may account for higher diversity during $\mathrm{BFA}_{\text {interglacial }}$ are 1) changes in the sedimentological processes with lower sediment baffling capacity of CWCs (up to $610 \mathrm{~cm} / \mathrm{ka}$ during Alleröd-YD and $21 \mathrm{~cm} / \mathrm{ka}$ in the Holocene; Stalder et al., 2015) due to decreased vertical aggradation of CWC structures during the Holocene and thus contributing to less dilution effects in the sedimentary records, 2) periodic lower sedimentation and winnowing at the seafloor favoring the accumulation of several generations of benthic foraminifera, which may lead to overestimation of the diversity in the paleorecord. Moreover, it has to be kept in mind that many small and/or fragile benthic foraminifera including agglutinated (e.g., B. nodosaria, Textularia spp.) and hyaline forms (e.g., Fissurina spp., Lagena spp.) have a poor preservation potential in the sedimentary records (e.g., Murray and Alve, 1999; Murray, 2006 and references therein).

The conspicuous distribution of Discanomalina coronata in the sediment cores raises the question whether this species can be used as an indicator for specific CWC growth conditions or not. Based on living (stained) and dead benthic foraminifera from surface samples of CWC ecosystems on the Celtic margin and the Norwegian shelf, Margreth et al. (2009) and Spezzaferri et al. (2013) suggested that the distribution of this species is mostly restricted to healthy CWC settings and that it may be used as a potential bioindicator for active (living) CWC reefs/ mounds. The occurrence of $D$. coronata is restricted to $\mathrm{BFA}_{\text {glacial }}$ and to highest benthic $\delta^{13} \mathrm{C}$ and $\delta^{18} \mathrm{O}$ values (Fig. 6) suggesting that this epibenthic species drives preferentially in cold and well-oxygenated waters. Stalder et al. (2015) have demonstrated that the distribution of $D$. coronata in core TTR17-401G corresponds to an interval characterized by highest and stable benthic $\delta^{13} \mathrm{C}$ and $\delta^{18} \mathrm{O}$ conductive of a high-diversified macrofaunal community and enhanced growth of L. pertusa. Since other epifaunal attached species (e.g., C. lobatulus, C. pachyderma, C. ungerianus) are frequent throughout all the cores, it is rather unlikely that $D$. coronata is only dependent on the availability of elevated substrates at the seafloor. Our radiocarbon dates show that $D$. coronata occurs at the end of MIS3 (33.3 ka BP) and during the Alleröd-early YD (13.1-12.6 ka BP). Both periods are characterized by relatively cold sea-surface temperatures and enhanced primary productivity in the Alboran Sea (Cacho et al., 2002; Martínez-Ruiz et al., 2015 and references therein) and by an intensification of the LIW flow (Toucanne et al., 2012).

Accordingly, we suggest that $D$. coronata develops under a relatively well-constrained bottom water density envelop with elevated oxygen concentrations and currents enriched in fresh food particles. This is well in agreement with the conclusions of Schönfeld (1997), Schönfeld and Zahn (2000) and Margreth et al. (2009) who found the "Epibenthos Group" including D. coronata on the Portuguese margin and the Rockall Plateau off Ireland mainly within the distribution of the MOW (600-1500 m water depth) characterized by a water density range of $\left(\sigma_{\theta}\right) 27.2-27.7 \mathrm{~kg} \mathrm{~m}^{-3}$ and relatively strong and streaming near-bottom currents $(12-51.1 \mathrm{~cm} / \mathrm{s})$ transporting suspended food particles (Zenk and Armi, 1990; Schönfeld, 1997; Dorschel et al., 2007). Such water mass characteristics and trophic level are known to be conductive of living CWCs (Dullo et al., 2008). We thus tentatively suggest that the ecological preferences of $D$. coronata fit within the ecological requirements for sustained CWC growth and in particular L. pertusa.

\subsection{Trophic level at the MMF in the last $34 \mathrm{ka}$}

The occurrence of Organic Rich Layers (ORL) or Sapropel-like layers are well referenced in the Mediterranean Sea (e.g., De Lange et al., 2008; Hennekam et al., 2014). The deposition of ORL1, which lasted from 14.5 to $8 \mathrm{ka}$, is characterized by enhanced primary productivity and dysoxic to anoxic bottom water conditions in the deep Alboran Basin (Jiménez-Espejo et al., 2008). Regarding the relatively old age obtained for the sediment at the base of core TTR17-399G and the two prominent TOC peaks displayed in the record (Fig. 2), the first peak is corresponding to the ORL2 (23-25.6 ka BP) less documented in the Alboran Sea (Cramp and O'Sullivan, 1999). Based on stable carbon isotopes of the organic fraction, Stalder et al. (2015) showed evidence for strong coupling between climate variability, water mass configuration and source/preservation of the $\mathrm{C}_{\text {org }}$ deposited at the MMF seafloor. The pseudo-Van Krevelen graph (Fig. 8) based on Rock-Eval data from the three sediment cores suggests a large variability in the source of the exported $\mathrm{C}_{\text {org }}$ with samples plotting in type I (lacustrine), type II (marine) and type III (terrestrial) kerogen fields (Espitalié et al., 1977; Tissot and Welte, 1984). Except for the samples from the base of core TTR17-396G (340 and $355 \mathrm{~cm}$ ), most samples display relatively low HI and high OI for typical shelf marine sediments. This can be explained by (i) high input of terrigenous organic matter (TOM), (ii) important contribution of partially reworked continental organic matter and/or (iii) strong oxidation of indigenous OM.

However, two different groups can be recognized, one composed by the samples belonging to $\mathrm{BFA}_{\text {glacial }}$ and one by $\mathrm{BFA}_{\text {interglacial }}$ (Fig. 8). $\mathrm{A}$ more detailed definition of the source of the $\mathrm{C}_{\text {org }}$ is displayed in the $\mathrm{S} 2$ versus TOC diagrams (Fig. 8) where the regression lines show a negative $\mathrm{x}$-intercept for all samples and thus indicates a general lack of S2 hydrocarbons (Langford and Blanc-Valleron, 1990). The sparse distribution of samples in the S2 versus TOC plot and the negligible correlation coefficient $\left(r^{2}=0.004\right)$ calculated from the linear regression line indicate that important differences in the source and the preservation of the OM deposited during $\mathrm{BFA}_{\text {glacial }}$ must have existed. Samples from the base of core TTR17-396G $(300-355 \mathrm{~cm})$ and in particular $(340-355 \mathrm{~cm})$ display higher S2 values compared to the other samples and thus strongly suggests: (i) rapid burial of lipid-rich (lacustrine) TOM remains in the sediments and/or (ii) deposition of relatively fresh organic matter produced by marine photoautotrophs that was not exposed to strong oxidation in the water column and in the sediments.

Typical marine and freshwater algae have $\mathrm{C} / \mathrm{N}$ ratios comprised between 4 and 10 whereas vascular land plants display values of $>20$ (Meyers and Ishiwatari, 1993; Meyers, 1994). The two lowermost samples display clearly higher values $\left(\mathrm{C}_{\text {org }} / \mathrm{N}_{\text {total }}=9.87\right.$ and 11.92) pointing towards a mixing with terrigenous material. Since the sediments at the base of this core are dated at $11 \mathrm{ka}$ BP and thus coincide with the onset of the African Humid Period, it is likely that part of the exported $\mathrm{OM}$ is of terrigenous origin. The negative excursions in the planktic $\delta^{13} \mathrm{C}$ and $\delta^{18} \mathrm{O}$ values within this interval corroborate well with the advection of isotopically light water from the continent, which may have supplied the MMF with TOM during enhanced river runoff or torrential flooding during the Alleröd-YD.

Without the four outliners, the correlation coefficient becomes higher $\left(r^{2}=0.12\right)$ but still low implying further large changes in the origin and/or the preservation of the deposited OM among the samples. Although a few samples plot well into the type II kerogen field, most samples plot at the boundary of type II and III kerogen field suggesting substantial admixing of TOM and extensive pre- and post-burial degradation. A succession of depleted planktic $\delta^{13} \mathrm{C}$ and $\delta^{18} \mathrm{O}$ during the interval covered by $\mathrm{BFA}_{\text {glacial }}$ and recognizable in all three cores supports well the periodic influence of freshwaters from the surrounding continents and/or the Atlantic Ocean.

An opposite trend can be recognized for the samples belonging to $\mathrm{BFA}_{\text {interglacial }}$ with a fairly high correlation coefficient $\left(\mathrm{r}^{2}=0.81\right)$ indicating a common source and/or preservation of the accumulated $\mathrm{OM}$ (Fig. 8). The regression line of samples $\mathrm{BFA}_{\text {interglacial }}$ plots well into type III kerogen field and thus suggests a mixture of highly degraded MOM together with a relatively important contribution of TOM, which is in good agreement with the constant HI of $82 \mathrm{mg} \mathrm{HC} / \mathrm{g}$ TOC from the slope of the regression line (Langford and Blanc-Valleron, 1990; Behar et al., 2001). Increased TOM input can be linked to the African Humid Period that lasted from 11 to $5 \mathrm{ka}$ and was characterized by prevailing humid and warm conditions with a widespread vegetation cover on the 

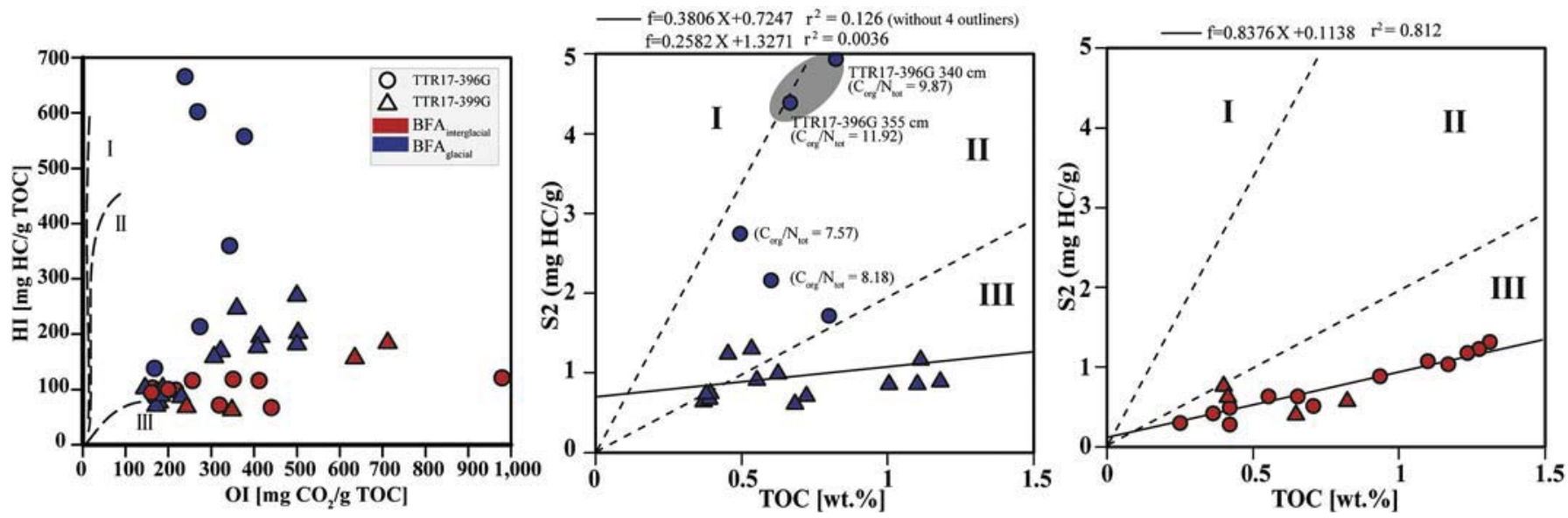

Fig. 8. Pseudo Van-Krevelen plots including the samples from the studied cores. Individual S2 versus TOC plots are showed for samples from $B F A_{\text {glacial }}$, BFA $A_{\text {interglacial }}$ and the surface samples. Boundaries of the kerogen typed fields are according to Langford and Blanc-Valleron (1990).

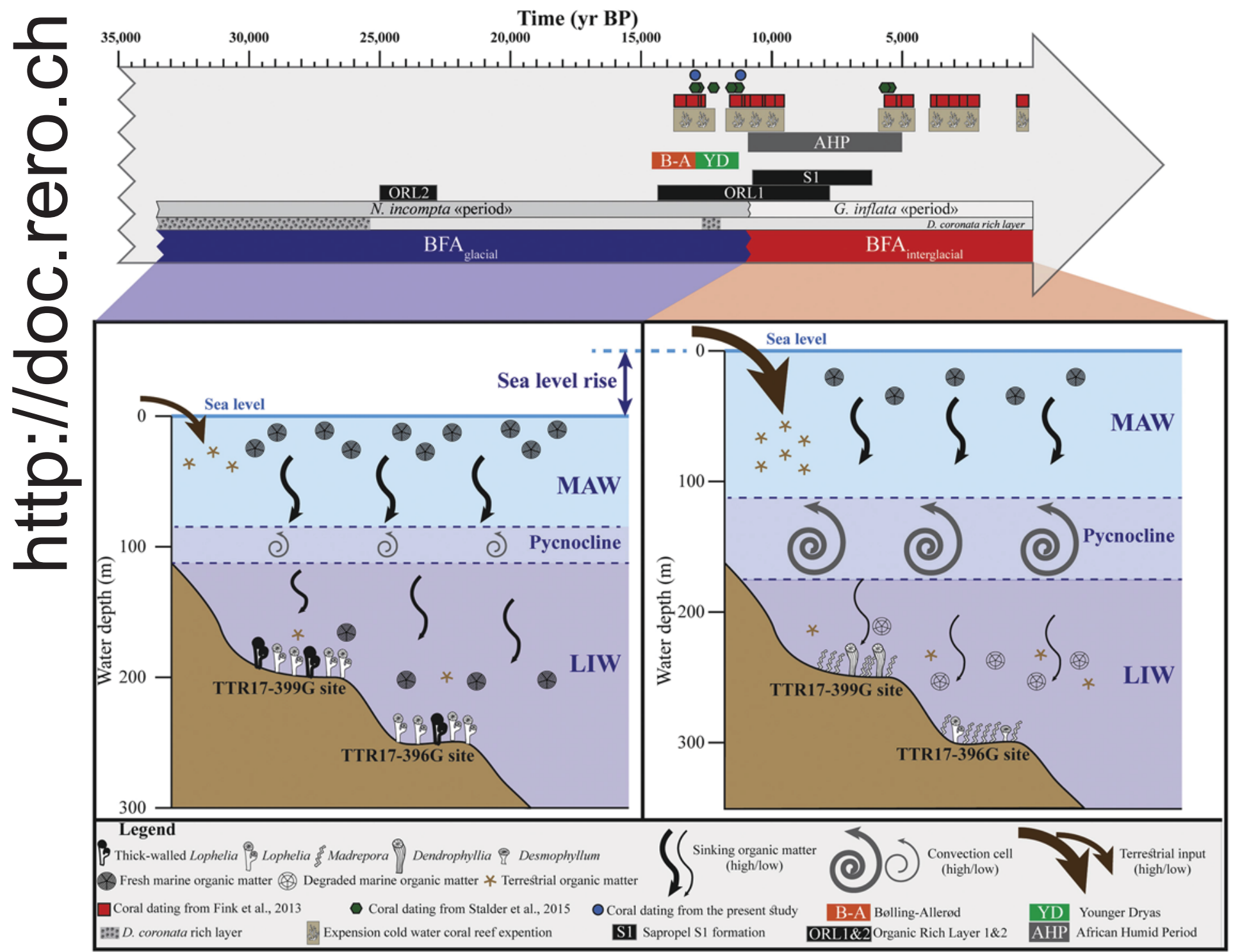

Fig. 9. Sketch showing the evolution of cold-water corals in the MMF during the last $33.3 \mathrm{ka}$. The time frame and the paleoceanographic conditions are inferred from radiocarbon dating, benthic foraminiferal assemblages (BFA), macrofaunal data, benthic and planktic $\delta^{13} \mathrm{C}$ and $\delta^{18} \mathrm{O}$, Rock-Eval pyrolysis and $\delta^{13} \mathrm{C}$. 
northern African continent (deMenocal et al., 2000). Extensive oxidation of MOM during $\mathrm{BFA}_{\text {interglacial }}$ is likely related to global sea-level rise and the consequent establishment of the modern oceanographic configuration in the Alboran Sea with a deepening of the pycno- and nutricline (Rohling et al., 1995). The higher water depth and the stronger density contrast during that time would have increased the residence time of the MOM exported to the seafloor and thus lead to more effective degradation and accumulation of refractory components. The $\delta^{13} \mathrm{C}_{\text {org }}$ values confirm clearly a higher contribution of TOM during the interval $\mathrm{BFA}_{\text {interglacial }}$ compared to $\mathrm{BFA}_{\text {glacial }}$ (Fig. 2).

\section{Conclusion}

The detailed study of benthic foraminifera and CWC fragments in two sediment cores allowed us to compare the response of the microand macrofauna to paleoceanographic variability during the last $33.3 \mathrm{ka} \mathrm{BP}$ in the eastern Alboran Sea and to test the following hypothesis elaborated in consortium with the data of a third sediment record (TTR17-401G) recovered from the same area (Stalder et al., 2015):

1) The benthic foraminifera assemblage $B A_{\text {glacial }}$ dominated by $C$. laevigata together with C. lobatulus, C. ungerianus, B. aculeata and $G$. subglobosa is indicative of elevated fluxes of labile organic carbon reaching the seafloor and cold and relatively well ventilated benthic conditions (Fig. 9). The interval $\mathrm{BFA}_{\text {glacial }}$ lasted at least from $33.3 \mathrm{ka}$ BP until the early Holocene $(\sim 11 \mathrm{ka} \mathrm{BP})$ and was characterized by the dominance of L. pertusa among the CWC community (Fig. 9).

2) The distribution of benthic foraminifera $D$. coronata is restricted to the intervals displaying the highest and most stable benthic $\delta^{13} \mathrm{C}$ and $\delta^{18} \mathrm{O}$ coinciding with enhanced CWC growth. This suggests that this species develops under specific ecological conditions including availability of elevated substrates and nutrient-rich near-bottom currents which may correspond to the most favourable growth conditions of CWC taxon such as L. pertusa.

3) The establishment of $\mathrm{BFA}_{\text {interglacial }}$ dominated by $B$. marginata with C. lobatulus, B. aculeata, C. laevigata and $U$. mediterranea marks the onset of the African Humid Period characterized by enhanced continental runoff and sediment transport to the MMF (Fig. 9). Most of this interval is missing in the shallower sediment cores displaying less favourable conditions at the benthic boundary layer with low ventilation and water energy and accumulation of organic carbon in the sediments (Fig. 9).

4) Combined to other radiocarbon dating of CWC fragments from the MMF (Fink et al., 2013), our data suggest that CWC growth was sustained in this area during the periods $13.5-12.2 \mathrm{ka}$ BP and 11.6-9.8 ka BP whereas it was interrupted during 5.8-9.8 ka BP. This is well in agreement with the prolific CWC growth episodes reported from the Mediterananean basin during the YD-early Holocene transition (McCullock et al., 2010).

5) Along the modern oceanographic configuration in the Alboran Sea, the water depth in the MMF increased and both the primary productivity and the quality of the deposited organic carbon decreased (Fig. 9). Moreover, our data provide evidence for admixing of terrigenous organic material from the narrow North African continent (Fig. 9). The Holocene benthic oceanographic conditions at the MMF offered however new ecological niches for many specialized and opportunistic benthic foraminifera taxa as demonstrated by higher diversity. In the CWC community, M. oculata and Dendrophyllids became dominant and provide further evidence for adaptive capacity of these taxa to changing environmental conditions.

\section{Acknowledgements}

We are greatly indebted to the Captain and crew of RV Professor Logatchev for their valuable help onboard. We thank Thierry Adatte for performing the Rock-Eval analyses. We are specially grateful to Henko de Stigter, Matias Reolid and two anonymous reviewer for their comments that considerably improved the manuscript. This study was funded by the Swiss National Foundation (projects 200020_131829 and 200020_153125). CS warmly acknowledges the Johanna Resig Cushman Foundation Fellowship 2014. AV and AR acknowledge the ESF COCARDE-ERN for favoring multidisciplinary collaborations.

\section{Appendix A. Supplementary data}

Supplementary data to this article can be found

\section{References}

Abu-Zied, R.H., Rohling, E.L., Jorissen, F.J., Fontanier, C., Casford, J.S.L., Cooke, S., 2008. Benthic foraminiferal response to changes in bottom-water oxygenation and organic carbon flux in the eastern Mediterranean during LGM to recent times. Mar. Micropaleontol. 67, 46-68.

Adkins, J., DdeMenocal, P., Eshel, G., 2006. The "African humid period" and the record ofmarine upwelling from excess 230Th in Ocean Drilling Program Hole 658C. Paleoceanography 21, 2006. https://doi.org/10.1029/2005PA001200.

Ammar, A., Mauffret, A., Gorini, C., Jabour, H., 2007. The tectonic structure of the Alboran Margin of Morocco. Rev. Soc. Geol. Esp. 20 (3-4), 247-271.

Antoine, D., Morel, A., André, J.M., 1995. Algal pigment distribution and primary production in the eastern Mediterranean Sea as derived from coastal zone color scanner observations. J. Geophys. Res. 100, 16193-16209.

Ausín, B., Flores, J.A., Sierro, F.J., Barcena, M.A., Hernández-Almeida, I., Frances, G., Guttierez-Arnillas, E., Martrat, B., Grimalt, J.O., Cacho, I., 2015. Coccolithophore productivity and surface water dynamics in the Alboran Sea during the last $25 \mathrm{kyr}$. Palaeogeogr. Palaeoclimatol. Palaeoecol. 418, 126-140.

Baldacci, A., Corsini, G., Grasso, R., Manzella, G., Allen, J., Cipollini, P., Guymer, T., Sanith, H., 2001. A study of the Alboran Sea mesoscale system by means of empirical orthogonal function decomposition of satellite data. J. Mar. Syst. 29, 293-311.

Barathon, J.J., El Abassi, H., Lechevalier, C., Malek, F., Jolly-Saad, M.C., 2000. Mise au point sur les formations holocènes dans le Rif oriental (Maroc). Géomorphologie: Relief Processus Environ. 6, 221-238.

Bartels-Jónsdóttir, H.B., Knudsen, K.L., Schönfeld, J., Lebreiro, S., Abrantes, F., 2006. Recent benthic foraminifera from the Tagus Prodelta and Estuary, Portugal: microhabitats, assemblage composition and stable isotopes. Zitteliana 46, 91-104.

Behar, F., Beaumont, V., De, B., Penteado, H.L., 2001. Rock-Eval 6 technology: performances and developments. Oil Gas Sci. Technol. 56, 111-134.

Bosc, E., Bricaud, A., Antoine, D., 2004. Seasonal and interannual variability in algal biomass and primary production in the Mediterranean Sea, as derived from 4 yeas of SeaWIFS observations. Global Biogeochem. Cycles 18, GB1005. https://doi.org/10. 1029/2003GB002034.

Bronk Ramsey, C., Scott, E.M., van der Plicht, J., 2013. Calibration for archaeological and environmental terrestrial 1288 samples in the time range $26-50 \mathrm{k}$ cal BP. Radiocarbon 55, 2021-2027.

Cacho, I., Grimalt, J.O., Sierro, F.J., Shackleton, N.J., Canals, M., 2000. Evidence for enhanced Mediterranean thermohaline circulation during rapid climatic coolings. Earth Planet. Sci. Lett. 183, 417-429.

Cacho, I., Grimalt, J.O., Canals, M., Sbaffi, L., Schackleton, N.J., Schönfeld, J., Zahn, R., 2001. Variability of the western Mediterranean sea surface temperatures during the last 25000 years and its connection with the Northern Hemisphere climatic changes. Paleoceanography 16, 40-52.

Cacho, I., Grimalt, J.O., Canals, M., 2002. Response of the western Mediterranean Sea to rapid climatic variability during the last 50,000 years: a molecular biomarker approach. J. Mar. Syst. 33, 253-272.

Caralp, M.H., 1988. Late glacial to recent deep-sea benthic foraminifera from the Northeastern Atlantic (Cadiz Gulf) and western Mediterranean (Alboran Sea): paleoceanographic results. Mar. Micropaleontol. 13, 265-289.

Caulle, C., Koho, K.A., Mojtahid, M., Reichart, G.J., Jorissen, F.J., 2014. Live (Rose Bengal stained) foraminiferal faunas from the northern Arabian Sea: faunal succession within and below the OMZ. Biogeosciences 11, 1155-1175.

Cimerman, F., Langer, M.R., 1991. Mediterranean foraminifera. Slovenska Akademi ja Znanosti in Umetnosti 30, 118.

Clarke, K., Gorley, R., 2006. Primer, 6th ed. Primer-E Ltd., Plymouth, UK.

Clarke, K.R., Warwick, R.M., 1994. Similarity-based testing for community pattern: the 2way layout with no replication. Mar. Biol. 118, 167-176.

Clarke, K.R., Warwick, R.M., 2001. A further biodiversity index applicable to species lists: variation in taxonomic distinctness. Mar. Ecol. Prog. Ser. 216, 265-278.

Comas, M., Pinheiro, L.M., 2007. Discovery of carbonate mounds in the Alboran Sea: the Melilla mounds field. In: Abstract for the First MAPG International Convention, Conference \& Exhibition Marrakech Convention Center, October 28-31.

Comas, M.C., Platt, J.P., Soto, J.I., Watts, A.B., 1999. The origin and tectonic history of 
the Alboran Basin; insights from LEG 161 results. Proc. Ocean Drilling Program Sci. Res. 161, 555-580.

Comas, M., Pinheiro, L.M., Ivanov, M., TTR-17 Leg 1 Scientific Party, 2009. Deep-water coral mounds in the Alboran Sea: the Melilla moundfield revisited. In: Comas, M. Suzyumov, A. (Eds.), Geo-Marine Research on the Mediterranean and European Atlantic Margins. International Conference and TTR-17 Post-Cruise Meeting of the Trainingthrough-Research Programme. UNESCO, Granada, Spain, pp. 8-9 2-5 February 2009, IOC Workshop Report No. 220.

Combourieu Nebout, N., Peyron, O., Dormoy, I., Desprat, S., Beaudouin, C., Kotthoff, U., Marret, F., 2009. Rapid climatic variability in the West Mediterranean during the last 25000 years from high resolution pollen data. Clim. Past 5, 503-521.

Corselli, C., 2010. The Aplabes programme. Physical, chemical and biological characterization of deep-water coral ecosystem from the Ionian Sea (Mediterranean). Deep-Sea Res. II 5, 323-492.

Cramp, A., O'Sullivan, G., 1999. Neogene sapropels in the Mediterranean: a review. Mar. Geol. 153, 11-28.

Davies, A.J., Wisshak, M., Orr, J.C., Roberts, J.M., 2008. Predicting suitable habitat for the cold-water coral Lophelia pertusa (Scleractinia). Deep-Sea Res. I 55, 1048-1062.

Davies, A.J., Duineveld, G., Lavaleye, M., Bergman, M., van Haren, H., Roberts, J.M., 2009. Downwelling and deep-water bottom currents as food supply mechanisms to the cold-water coral Lophelia pertusa (Scleractinia) at the Mingulay Reef Complex. Limnol. Oceanogr. 54, 620-629.

De Lange, G.J., Thomson, J., Reitz, A., Slomp, C.P., Speranza Principato, M., Erba, E., Corselli, C., 2008. Synchronous basin-wide formation and redox-controlled preservation of a Mediterranean sapropel. Nat. Geosci. 1, 606-610.

De Rijk, S., Jorissen, F.J., Rohling, E.J., Troelstra, S.R., 2000. Organic flux control on bathymetric zonation of Mediterranean benthic foraminifera. Mar. Micropaleontol. 40, 151-166.

De Stigter, H.C., Jorissen, F.J., Zwaan van der, G.J., 1998. Bathymetric distribution and microhabitat partitioning of live (rose bengal stained) benthicforaminifera along a shelf to bathyal transect in the southern Adriatic Sea. J. Foram. Res. 28, 40-65.

Dela Pierre, F., Clari, P., Bernardi, E., Natalicchio, M., Cost, E., Cavagna, S., Lozar, F, Lugli, S., Manzi, V., Roveri, M., Violanti, D., 2012. Messinian carbonate-rich beds of the Tertiary Piedmont Basin (NW Italy): microbially-mediated products straddling the onset of the salinity crisis. Palaeogeogr. Palaeoclimatol. Palaeoecol. 344-345, $78-93$.

deMenocal, P. B., Ortiz, J., Guilderson, T., Adkins, J., Sarnthein, M., Baker, L., Yarusinski, M., 2000. Abrupt onset and termination of the African Humid Period: rapid climate response to gradual insolation forcing. Quat. Sci. Rev. 19, 347-361.

Di Geronimo, I., Messina, C., Rosso, A., Sanfilippo, R., Sciuto, F., Vertino, A., 2005. Enhanced biodiversità in the deep: early Pleistocene coral communities from southern Italy. In: Freiwald, A., Roberts, J.M. (Eds.), Cold-Water Corals Ecosystems. Springer-Verlag, Berlin, Heidelberg, pp. 61-86.

Donnici, S., Barbero, R.S., 2002. The benthic foraminiferal communities of the northern Adriatic continental shelf. Mar. Micropaleontol. 44, 93-123.

Dorschel, B., Hebbeln, D., Rüggeberg, A., Dullo, C., 2007. Carbonate budget of a coldwater coral carbonate mound: propeller mound, Porcupine Seabight. Int. J. Earth Sci. 96, 73-83.

Drinia, H., Antonarakou, A., Tsaparas, N., Dermitzakis, M.D., 2007. Foraminiferal stratigraphy and palaeoecological implications in turbidite-like deposits from the Early Tortonian (Late Miocene) of Greece. J. Micropalaeontol. 26, 145-158.

Drinia, H., Antonarakou, A., Anastasakis, G., 2014. Late quaternary micropalaeontological record of a semi-enclosed marine basin, north Evoikos, central Aegean Sea. Quat. Int. 345, 18-31.

Dullo, W.-C., Flögel, S., Rüggeberg, A., 2008. Cold-water coral growth in relation to the hydrography of the Celtic and Nordic European continental margin. Mar. Ecol.-Prog. Ser. 371, 165-176.

Eide, L.I., 1979. Evidence of a topographically trapped vortex on the Norwegian continental shelf. Deep-Sea Res. I 26, 601-621.

Emeis, K.-C., Sakamoto, T., 1998. The sapropel theme of Leg 160. In: Robertson, A.H.F. Emeis, K.-C., Richter, C., Camerlenghi, A. (Eds.), Proc. ODP, Sci. Results, 160. Ocean Drilling Program, College Station, TX, pp. 29-36.

Espitalié, J., Laporte, J.L., Madec, M., Marquis, F., Leplat, P., Paulet, J., Boutefeu, A., 1977. Méthode rapide de caractérisation des roches mères, de leur potentiel pétrolier et de leur degré d'évolution. Rev. Inst. Fr. Pétrol. 32, 23-42.

Espitalié, J., Deroo, G., Marquis, F., 1986. La pyrolyse Rock-Eval et ses applications. Oil Gas Sci. Technol. 41, 73-89.

Fabrés, J., Calafat, A., Sánchez-Vidal, A., Canals, M., Heussner, S., 2002. Composition and spatio-temporal variability of particle fluxes in the western Alboran Gyre, Mediterranean Sea. J. Mar. Syst. 33-34, 431-456.

Fariduddin, M., Loubere, P., 1977. The surface ocean productivity response of deeper water benthic foraminifera in the Atlantic Ocean. Mar. Micropaleontol. 32, 289-310.

Fink, H.G., Wienberg, C., De Pol-Holz, R., Wintersteller, P., Hebbeln, D., 2013. Cold-water coral growth in the Alboran Sea related to high productivity during the Late Pleistocene and Holocene. Mar. Geol. 339, 71-82.

Fink, H.G., Wienberg, C., De Pol-Holz, R., Hebbeln, D., 2015. Spatio-temporal distribution patterns of Mediterranean cold-water corals (Lophelia pertusa and Madrepora oculata) during the past 14,000 years. Deap-Sea Res. I 103, 37-48.

Fletcher, W.J., Sanchez-Goñi, M.F., Peyron, O., Dormoy, I., 2010. Abrupt climate changes of the last deglaciation detected in a western Mediterranean forest record. Clim. Past 6, 245-264.

Font, J., Millot, C., Salas, J., Julià, A., Chic, O., 1998. The drift of Modified Atlantic Water from the Alboran Sea to the eastern Mediterranean. Sci. Mar. 62, 211-216.

Fontanier, C., Jorissen, F.J., Licari, L., Alexandre, A., Anschutz, P., Carbonel, P., 2002. Live benthic foraminiferal faunas from the Bay of Biscay: faunal density, composition and microhabitats. Deep-Sea Res. I 49, 751-785.
Foubert, A., Van Rooij, D., Blamart, D., Henriet, J.-P., 2007. X-ray imagery and physical core logging as a proxy of the content of sediment cores in cold-water coral mound provinces: a case study from Porcupine Seabight SW of Ireland. Int. J. Earth Sci. (Geol Rundsch) 96, 141-158.

Frank, N., Ricard, E., Lutringer-Paquet, A., van der Land, C., Colin, C., Blamart, D., Foubert, A., Van Rooij, D., Henriet, J.-P., de Haas, H., van Weering, T., 2009. The Holocene occurrence of cold water corals in the NE Atlantic: implications for coral carbonate mound evolution. Mar. Geol. 266, 129-142.

Freiwald, A., Fossa, J.H., Grehan, A., Koslow, T., Roberts, J.M., 2004. Cold-Water Coral Reefs. UNEP-WCMC, Cambridge, pp. 85.

Freiwald, A., Beuck, L., Rüggeberg, A., Taviani, M., Hebbeln, D., 2009. The white coral community in the central Mediterranean Sea revealed by ROV surveys. Oceanography 22, 58-74.

Frigola, J., Moreno, A., Cacho, I., Canals, M., Sierro, F.J., Flores, J.A., Grimalt, J.O, Hodell, D.A., Curtis, J.H., 2007. Holocene climate variability in the western Mediterranean region from a deepwater sediment record. Paleoceanography 22 , PA2209. https://doi.org/10.1029/2006PA001307.

Frigola, J., Moreno, A., Cacho, I., Canals, M., Sierro, F.J., Flores, J.A., Grimalt, J.O., 2008. Evidence of abrupt changes in western Mediterranean deep water circulation during the last 50 kyr: a high-resolution marine record from the Balearic Sea. Quat. Int. 181 (1), 88-104.

Geslin, E., Heinz, P., Jorissen, F., Hemleben, Ch., 2004. Migratory responses of deep-sea benthic foraminifera to variable, oxygen conditions: laboratory investigations. Mar. Micropaleontol. 53, 227-243.

Gooday, A.J., 1993. Deep-sea benthic foraminiferal species which exploit phytodetritus: characteristic features and controls on distribution. Mar. Micropaleontol. 22, 187-205.

Gooday, A.J., 1994. The biology of deep-sea foraminifera: a review of some advances and their applications in paleoceanography. PALAIOS 9, 14-31.

Gori, A., Orejas, C., Madurell, T., Bramanti, L., Martins, M., Quintanilla, E., Marti-Puig, P., Lo Iacono, C., Puig, P., Requena, S., Greenacre, M., Gili, J.M., 2013. Bathymetrical distribution and size structure of cold-water coral populations in the Cap de Creus and Lacaze-Duthiers canyons (northwestern Mediterranean). Biogeosciences 10, 2049-2060. https://doi.org/10.5194/bg-10-2049-2013.

Hamann, Y., Ehrmann, W., Schmiedl, G., Krüger, S., Stuut, J.-B., Kuhnt, T., 2008. Sedimentation processes in the eastern Mediterranean Sea during the Late Glacial and Holocene as revealed by end-member modelling. Mar. Geol. 248, 97-114.

Hebbeln, D., Wienberg, C., Beuck, L., Freiwald, A., Wintersteller, P., cruise participants, 2009. Report and preliminary results of RV POSEIDON cruise POS 385 'Cold-Water Corals of the Alboran Sea (western Mediterranean Sea)', May-June 2009. Fachbereich Geowissenschaften, Universität Bremen, Faro-Toulon. Berichte, pp. 79 No. 273.

Heburn, G.W., La Violette, P.E., 1990. Variations in the structure of the anticyclonic gyres found in the Alboran Sea. J. Geophys. Res. 95, 1599-1613.

Hennekam, R., Jilbert, T., Schnetger, B., De Lange, G.J., 2014. Solar forcing of Nile discharge and sapropel S1 formation in the early to middle Holocene eastern Mediterranean. Paleoceanography 29https://doi.org/10.1002/2013PA002553. 2013PA002553.

Hilgen, F.J., 1991. Astronomical calibration of Gauss to Matuyama sapropels in the Mediterranean and implication for the geomagetic polarity time scale. Earth Planet. Sci. Lett. 104, 226-244.

Iorga, M.C., Lozier, M.S., 1999. Signatures of the Mediterranean outflow from a North Atlantic climatology: salinity and density fields. J. Geophys. Res. 104, 25985-26009.

Jiménez-Espejo, F.J., Martínez-Ruiz, F., Finlayson, C., Paytan, A., Sakamoto, T., OrtegaHuertas, M., Finlayson, G., Iijima, K., Gallego-Torres, D., Fa, D., 2007. Climate forcing and Neanderthal extinction in Southern Iberia: insights from a multiproxy marine record. Quat. Sci. Rev. 26, 836-852.

Jiménez-Espejo, F.J., Matínez-Ruiz, F., Rogerson, M., Gonzales-Donoso, J.M., Romero, O.E., Linares, D., Sakamoto, T., Gallego-Torres, D., Rueda Ruiz, J.L., Ortega-Huertas, M., Perez Claros, J.A., 2008. Detrital input, productivity fluctuations, and water mass circulation in the westernmost Mediterranean Sea since the Last Glacial Maximum. Geochem. Geophys. Geosyst. 9, QU11U02. https://doi.org/10.1029/2008GC002096.

Jorissen, F.J., 1987. The distribution of benthonic foraminifera in the Adriatic Sea. Mar. Micropaleontol. 12, 21-48.

Koho, K.A., Langezaal, A.M., van Lith, Y.A., Duijnstee, I.A.P., van der Zwaan, G.J., 2008. The influence of a simulated diatom bloom on deep sea benthic foraminifera and the activity of bacteria: a mesocosm study. Deep-Sea Res. I 55, 696-719.

La Violette, P.E., 1986. Short term measurements of surface currents associated with the Alboran Sea during Donde Va? J. Phys. Oceanogr. 16 (2), 262-279.

Lambeck, K., Antonioli, F., Anzidei, M., Ferranti, L., Leoni, G., Scicchitano, G., Silenzi, S., 2011. Sea level change along the Italian coast during the Holocene and projections for the future. Quat. Int. 232, 250-257.

Langford, F.F., Blanc-Valleron, M.-M., 1990. Interpreting Rock-Eval pyrolysis data using graphs of pyrolizable hydrocarbons vs. total organic carbon. Am. Assoc. Pet. Geol. Bull. 74, 799-804.

Levy, A., Mathieu, R., Poignant, A., Rosset-Moulinier, M., Ambroise, D., 1995. Benthic foraminifera from the Fernando de Noronha Archipelago (northern Brazil). Mar Micropaleontol. 26, 89-97.

Lindberg, B., Mienert, J., 2005. Post-glacial carbonate production by cold-water corals on the Norwegian Shelf and their role in the global carbonate budget. Geology 33, 537-540.

Linke, P., Lutze, G.F., 1993. Microhabitat preferences of benthic foraminifera—a static concept or a dynamic adaptation to optimize food acquisition? Mar. Micropaleontol. $20,215-234$.

Liu, Q., Larrasoana, J.C., Torrent, J., Roberts, A.P., Rohling, E.J., Liu, Z., Jiang, Z., 2012. New constraints on climate forcing and variability in the circum- Mediterranean 
region from magnetic and geochemical observations of sapropels S1, S5 and S6. Palaeogeogr. Palaeoclimatol. Palaeoecol. 333-334, 1-12.

Lo Iacono, C., Gracia, E., Ranero, C., Emelianov, M., Huvenne, V.A.I., Bartolome, R. Booth-Rea, G., Prades, J., MELCOR Cruise party, 2014. The West Melilla cold water coral mounds, eastern Alboran Sea: morphological characterization and environmental context. Deep-Sea Res. II 99, 316-326.

López Correa, M., Montagna, P., Joseph, N., Rüggeberg, A., Fietzke, J., Flögel, S., Dorschel, B., Goldstein, S.L., Wheeler, A., Freiwald, A., 2012. Preboreal onset of Norwegian cold-water coral growth beyond the Arctic Circle revealed by radiocarbon and U-series dating and neodymium isotopes. Quat. Sci. Rev. 34, 24-43.

Lutze, G.F., Coulbourn, W.T., 1984. Recent benthic foraminifera from the continental margin of Northwest Africa: community structure and distribution. Mar. Micropaleontol. 8, 361-401.

Mackensen, A., Schmiedl, D.K., Harloff, J., Giese, M., 1995. Deep-sea foraminifera in the South Atlantic Ocean: ecology and assemblage generation. Mar. Micropaleontol. 41, 342-358.

Malinverno, E., Taviani, M., Rosso, A., Violanti, D., Villa, I., Savini, A., Vertino, A., Remia, A., Corselli, C., 2010. Stratigraphic framework of the Apulian deep-water coral province. Ionian Sea. Deep-Sea Res. II 57, 345-359.

Margreth, S., 2010. Benthic foraminifera associated to cold-water coral ecosystems. In $\mathrm{PhD}$ Thesis, Geofocus 24. Department of Geosciences, University of Fribourg, Switzerland, pp. 248.

Margreth, S., Rüggeberg, A., Spezzaferri, S., 2009. Benthic foraminifera as proxies for cold-water coral reef ecosystems along the Irish margin. Deep-Sea Res. I 56, 2216-2234.

Margreth, S., Gennari, G., Rüggeberg, A., Comas, M.C., Pinheiro, L.M., Spezzaferri, S., 2011. Growth and demise of cold-water coral ecosystems on mud volcanoes in the West Alboran Sea: the messages from the planktonic and benthic foraminifera. Mar. Geol. 282, 26-39.

Martínez-Ruiz, F., Kastner, M., Gallego-Torres, D., Rodrigo-Gamiz, M., Nieto-Moreno, V., Ortega-Huertas, M., 2015. Paleoclimate and paleoceanography over the past 20,000 yr in the Mediterranean Sea Basins as indicated by sediment elemental proxies. Quat. Sci. Rev. 107, 25-46.

Martins, V., Jouanneau, J.-M., Weber, O., Rocha, F., 2006. Tracing the late Holocene evolution of the NW Iberian upwelling system. Mar. Micropaleontol. 59, 35-55.

Mastrototaro, F., Donghia, G., Corriero, G., Matarrese, A., Maiorano, P., Panetta, P., Gherardi, M., Longo, C., Rosso, A., Sciuto, F., Sanfilippo, R., Gravili, C., Boero, F., Taviani, M., Tursi, A., 2010. Biodiversity of the white coral bank off Cape Santa Maria di Leuca (Mediterranean Sea): an update. Deep-Sea Res. II 57, 412-430.

McCullock, M., Taviani, M., Montagna, P., López Correa, M., Remia, A., Mortimer, G., 2010. Proliferation and demise of deep-sea corals in the Mediterranean during the Younger Dryas. Earth Planet. Sci. Lett. 298, 143-152.

Meyers, P.A., 1994. Preservation of elemental and isotopic source identification of sedimentary organic matter. Chem. Geol. 114, 289-302.

Meyers, P.A., Ishiwatari, R., 1993. Lacustrine organic geochemistry-an overview of indicators of organic matter sources and diagenisis in lake sediments. Org. Geochem. 20 (7), 867-900.

Milker, Y., Schmiedl, G., 2012. A taxonomic guide to modern benthic shelf foraminifera of the western Mediterranean Sea. Palaeontol. Electronica 15 (2), 134.

Milker, Y., Schmiedl, G., Betzler, C., Römer, M., Jaramillo-Vogel, D., Siccha, M., 2009. Distribution of recent benthic foraminifera in neritic carbonate environments of the western Mediterranean Sea. Mar. Micropaleontol. 73, 207-225.

Millot, C., Candela, J., Fuda, J.L., Tber, Y., 2006. Large warming and salinification of the Mediterranean outflow due to changes in its composition. Deep-Sea Res. I 53 , 656-666.

Mojtahid, M., Jorissen, F., Durrieu, J., Galgani, F., Howa, H., Redois, F., Camps, R., 2006. Benthic foraminifera as bio-indicators of drill cutting disposal in tropical East Atlantic outer shelf environments. Mar. Micropaleontol. 61, 58-75.

Mojtahid, M., Jorissen, F., Lansard, B., Fontanier, C., Bombled, B., Rabouille, C., 2009. Spatial distribution of live benthic foraminifera in the Rhône prodelta: faunal response to a continental-marine organic matter gradient. Mar. Micropaleontol. 70, $177-200$.

Movilla, J., Orejas, C., Calvo, E., Gori, A., Lopez-Sanz, A., Grinyó, J., Domínguez-Carrió, C., Pelejero, C., 2014. Differential response of two Mediterranean cold-water coral species to ocean acidification. Coral Reefs 33 (3), 675-686.

Murray, J.W., 2006. Ecology and Applications of Benthic Foraminifera. Cambridge University Press, Cambridge, pp. 426.

Murray, J.W., Alve, E., 1999. Natural dissolution of shallow water benthic foraminifera: taphonomic effects on the palaeoecological record. Palaeogeogr. Palaeoclimatol. Palaeoecol. 146, 195-209.

Nomaki, H., Heinz, P., Nakatsuka, T., Shimanaga, M., Ohkouchi, N., Ogawa, N.O., Kogure, K., Ikemoto, E., Kitazato, H., 2006. Different ingestion patterns of ${ }^{13} \mathrm{C}$-labeled bacteria and algae by deep-sea benthic foraminifera. Mar. Ecol.-Prog. Ser. 310, 95-108.

Orejas, C., Gori, A., Iacono, C.L., Puig, P., Gili, J.-M., Dale, M.R.T., 2009. Cold-water corals in the Cap de Creus canyon, Northwestern Mediterranean: spatial distribution, density and anthropogenic impact. Mar. Ecol.-Prog. Ser. 397, 37-51.

Raddatz, J., Rüggeberg, A., Margreth, S., Dullo, W.Chr, the IODP Expedition 307 Scientific Party, 2011. Paleoenvironmental reconstruction of Challenger Mound initiation in the Porcupine Seabight, NE Atlantic. Mar. Geol. 282, 79-90.

Raddatz, J., Rüggeberg, A., Liebtrau, V., Foubert, A., Hathorne, Ed.C., Fietzke, J., Eisenhauer, A., Dullo, W.-C., 2014. Environmental boundary conditions of cold-water coral mound growth over the last 3 million years in the Porcupine Seabight Northeast Atlantic. Deep-Sea Res. II 99, 227-236.

Reimer, P., Bard, E., Bayliss, A., Beck, J., Blackwell, P., Bronk Ramsey, C., Buck, C.E., Cheng, H., Edwards, R.L., Friedrich, M., Grootes, P.M., Guilderson, T.P., Haflidason,
H., Hajdas, I., Hatté, C., Heaton, T.J., Hoffmann, D.L., Hogg, A.G., Hughen, K.A., Kaiser, K.F., Kromer, B., Manning, S.W., Niu, M., Reimer, R.W., Richards, D.A., Scott, E.M., Southon, J.R., Staff, R.A., Turney, C.S.M., van der Plicht, J., 2013. IntCal13 and Marine13 radiocarbon age calibration curves 0-50,000 years cal BP. Radiocarbon 55 (4), 1869-1887.

Renault, L., Oguz, T., Pascual, A., Vizoso, G., Tintore, J., 2012. Surface circulation in the Alborán Sea (western Mediterranean) inferred from remotely sensed data. J. Geophys. Res. 117. https://doi.org/10.1029/2011JC007659.

Reolid, J., Betzler, C., Singler, V., Stange, C., Lindhorst, S., 2017. Facies variability in mixed carbonate-siliciclastic platform slopes (Miocene). Facies 63 (11). https://doi. org/10.1007/s10347-016-0489-1.

Revel, M., Colin, C., Bernasconi, S., Combourieu-Nebout, N., Ducassou, E., Grousset, F., Rolland, Y., Migeon, S., Bosch, D., Brunet, P., Zhao, Y., Mascle, J., 2014. 21000 years of Ethiopian African monsoon variability recorded in sediments of the western Nile deep-sea fan. Reg. Environ. Chang. 14, 1685-1696.

Roberts, J.M., Wheeler, A.J., Freiwald, A., 2006. Reefs of the deep: the biology and geology of cold-water coral ecosystems. Science 312, 543-547.

Rohling, E.J., 1994. Review and new aspects concerning the formation of Mediterranean sapropels. Mar. Geol. 122, 1-28.

Rohling, E.J., De Rijk, S., 1999. Holocene climate optimum and last glacial maximum in the Mediterranean: the marine oxygen isotope record. Mar. Geol. 153, 57-75.

Rohling, E.J., Den Dulk, M., Pujol, C., Vergnaud-Grazzini, C., 1995. Abrupt hydrographic change in the Alboran Sea (western Mediterranean) around 8000 yrs BP. Deep-Sea Res. I 42, 1609-1619.

Rossignol-Strick, M., 1985. Mediterranean quaternary sapropels, an immediate response of the African monsoon to variation of insolation. Palaeogeogr. Palaeoclimatol. Palaeoecol. 49, 237-263.

Rüggeberg, A., Dullo, C., Dorschel, B., Hebbeln, D., 2007. Environmental changes and growth history of Propeller Mound, Porcupine Seabight: evidence from benthic foraminiferal assemblages. Int. J. Earth Sci. 96, 57-72.

Sabelli, B., Taviani, M., 1984. Red Sea record of a Fungia-associated Epitoniid. Bolletino Malacologico 20, 91-94.

Sanfilippo, R., Vertino, A., Rosso, A., Beuck, L., Freiwald, A., Taviani, M., 2013. Serpula aggregates and their role in deep-sea coral communities in the Adriatic Sea. Facies 59, 663-677.

Sarhan, T., García-Lafuente, J., Vargas, J.M., Plaza, F., 2000. Upwelling mechanisms in the northwestern Alboran Sea. J. Mar. Syst. 23, 317-331.

Savini, A., Vertino, A., Marchese, F., Beuck, L., Freiwald, A., 2014. Mapping cold-water coral habitats at different scales within the Northern Ionian Sea (Central Mediterranean): an assessment of coral coverage and associated vulnerability. PLoS One 9 (1), e87108. https://doi.org/10.1371/journal.pone.0087108.

Schmiedl, G., Mackensen, A., 1997. Late Quaternary paleoproductivity and deep water circulation in the eastern South Altantic Ocean: evidence from benthic foraminifera. Palaeogeogr. Palaeoclimatol. Palaeoecol. 130, 43-80.

Schmiedl, G., Mackensen, A., Müller, P.J., 1997. Recent benthic foraminifera from the eastern South Atlantic Ocean: dependence on food supply and water masses. Mar. Micropaleontol. 32, 249-287.

Schmiedl, G., Hemleben, C., Keller, J., Segl, M., 1998. Impact of climatic changes on the benthic foraminiferal fauna in the Ionian Sea during the last 330,000 years. Paleoceanography $13,447-458$.

Schmiedl, G., de Bovée, F., Buscail, R., Charrière, B., Hemleben, C., Medernach, L., Picon, P., 2000. Trophic control of benthic foraminiferal abundance and microhabitat in the bathyal Gulf of Lions, western Mediterranean Sea. Mar. Micropaleontol. 40, 167-188.

Schmiedl, G., Mitschele, A., Beck, S., Emeis, K.-C., Hemleben, C., Schulz, H., Sperling, M., Weldeab, S., 2003. Benthic foraminiferal record of ecosystem variability in the eastern Mediterranean Sea during times of sapropel S5 and S6 formation. Palaeogeogr. Palaeoclimatol. Palaeoecol. 190, 139-164.

Schmiedl, G., Kuhnt, T., Ehrmann, W., Emeis, K.-C., Hamann, Y., Kotthoff, U., Dulski, P., Pross, J., 2010. Climatic forcing of eastern Mediterranean deep-water formation and benthic ecosystems during the past 22000 years. Quat. Sci. Rev. 29, 3006-3020.

Schönfeld, J., 1997. The impact of Mediterranean Outflow Water (MOW) on benthic foraminiferal assemblages and surface sediments at the southern Portuguese margin. Mar. Micropaleontol. 29, 211-236.

Schönfeld, J., 2002. A new benthic foraminiferal proxy for near-bottom current velocities in the Gulf of Cadiz, northeastern Atlantic Ocean. Deep-Sea Res. I 49 (10), 1853-1875.

Schönfeld, J., Zahn, R., 2000. Late Glacial to Holocene history of the Mediterranean Outflow. Evidence from benthic foraminiferal assemblages and stable isotopes at the Portuguese margin. Palaeogeogr. Palaeoclimatol. Palaeoecol. 159 (1-2), 85-111.

Schönfeld, J., Dullo, W.C., Pfannkuche, O., Freiwald, A., Rüggeberg, A., Schmidt, S, Weston, J., 2011. Recent benthic foraminiferal assemblages from cold-water coral mounds in the Porcupine Seabight. Facies 57, 187-213.

Sciuto, F., Rosso, A., 2015. Bathyal ostracods from the Santa Maria di Leuca deep-water coral province (northern Ionian Sea). Palaeontol. Electronica 18.2.22A.

Sen Gupta, B.K., Lee, R.F., May III, M.S., 1981. Upwelling and an unusual assemblage of benthic foraminifera on the northern Florida continental slope. J. Paleontol. 55, 853-857.

Sierro, F.J., Flores, J.A., Barcena, M.A., Vasquez, A., Utrilla, R., Zamarreno, I., 2003. Orbitally-controlled oscillations in the planktic communities and cyclical changes in western Mediterranean hydrography during the Messinian. Palaeogeogr. Palaeoclimatol. Palaeoecol. 190, 289-316.

Smeulders, G.G.B., Koho, K.A., de Stiger, H.C., Mienis, F., de Haas, H., van Weering, T.C.E., 2014. Cold-water coral habitats of Rockall and porcupine Bank, NE Atlantic Ocean: sedimentary facies and benthic foraminiferal assemblages. Deep-Sea Res. II 99, 270-285.

Spezzaferri, S., Coric, S., 2001. Ecology of Karpatian (Early Miocene) foraminifers and 
calcareous nannoplankton from Laa an der Thaya, Lower Austria: a statistical approach. Geol. Carpath. 52 (6), 361-374.

Spezzaferri, S., Rüggeberg, A., Stalder, C., Margreth, S., 2013. Benthic foraminifera from Norwegian cold-water coral reefs. J. Foram. Res. 43, 21-39.

Spezzaferri, S., Rüggeberg, A., Stalder, C., 2015. Atlas of benthic foraminifera from coldwater coral reefs. Cushman Foundation Foraminiferal Res. 44, 367 Special Publication.

Stalder, C., Spezzaferri, S., Rügreberg, A., Pirkenseer, C., Gennari, G., 2014. Late Weichselian deglaciation and early Holocene development of a cold-water coral reef along the Lopphavet shelf (northern Norway) recorded by benthic foraminifera and ostracoda. Deep-Sea Res. II 99, 249-269.

Stalder, C., Vertino, A., Rüggeberg, A., Pirkenseer, C., Camozzi, O., Rappo, S., Rosso, A., Spangenberg, J.E., Hajdas, I., Spezzaferri, S., 2015. Microfossils, a key to unravel cold-water carbonate mound evolution through time: evidence from the eastern Alboran Sea. PLoS One 10 (10), e0140223.

Suhr, S.B., Pond, D.W., Gooday, A.J., Smith, C.R., 2003. Selective feeding by benthic foraminifera on phytodetritus on the western Antarctic Peninsula shelf: evidence from fatty acid biomarker analysis. Mar. Ecol.-Prog. Ser. 262, 153-162.

Taviani, M., Freiwald, A., Zibrowius, H., 2005. Deep coral growth in the Mediterranean Sea: an overview. In: Freiwald, A., Roberts, J.M. (Eds.), Cold-Water Corals and Ecosystems. Springer-Verlag, Berlin, Heidelberg, New York, pp. 137-156.

Tissot, B.P., Welte, D.H., 1984. Petroleum Formation and Occurrence, 2nd ed. Springer, New York, pp. 699.

Titschack, J., Thierens, M., Dorschel, B., Schulbert, C., Freiwald, A., Kano, A., Takashima, C., Kawagoe, N., Li, X., IODP Expedition 307 Scientific Party, 2009. Carbonate budget of a cold-water coral mound (Challenger Mound, IODP Exp. 307). Mar. Geol. 259, $36-46$.

Titschack, J., Baum, D., De Pol-Holz, R., López Correa, M., Foster, N., Flögel, S., Hebbeln, D., Freiwald, A., 2015. Aggradation and carbonate accumulation of Holocene Norwegian cold-water coral reefs. Sedimentology 62, 1873-1898.

Titschack, J., Kink, H.G., Baum, D., Wienberg, C., Hebbeln, D., Freiwald, A., 2016.

Mediterranean cold-water corals - an important regional carbonate factory? Depositional Record 2 (1), 74-96.

Toucanne, S., Jouet, G., Ducassou, E., Bassetti, M.-A., Dennielou, B., Minto'o, C.M.A., Lahmi, M., Touyet, N., Charlier, K., Lericolais, G., Mulder, T., 2012. A 130,000-year record of Levantine Intermediate Water flow variability in the Corsica Trough, western Mediterranean Sea. Quat. Sci. Rev. 33, 55-73.

Tunesi, L., Diviacco, G., Mo, G., 2001. Observations by submersible on the biocenosis of the deep-sea corals off Portofino Promontory (Northwestern Mediterranean Sea). In: Willison, J.H., Hall, J., Gass, S.E., Kenchington, E.L.R., Butler, M., Doherty, P. (Eds.), Deep-Sea Corals. Ecology Action Centre, pp. 76-87.

Turley, C.M., Roberts, J.M., Guinotte, J.M., 2007. Corals in deep-water: will the unseen hand of ocean acidification destroy cold-water ecosystems? Coral Reefs 26 (3), 445-448.

Vafidis, D., Koukouras, A., Voultsiadou-Koukoura, E., 1997. Actinaria, Corallimorpharia, and Scleractinia (Hexacorallia, Anthozoa) of the Aegean Sea, with a checklist of the eastern Mediterranean and Black Sea species. Isr. J. Zool. 43, 55-70.

Van der Zwaan, G.J., Jorissen, F.J., 1991. Biofacial patterns in river-induced shelf anoxia. In: Tyson, R.V., Pearson, T.H. (Eds.), Modern and Ancient Continental Shelf Anoxia. 58. Geol. Soc. London Spec. Publ., pp. 65-82.

van Haren, H., Millot, C., 2004. Rectilinear and circular inertial motions in the western Mediterranean Sea. Deep-Sea Res. I 51, 1441-1455.

Van Rooij, D., Hebbeln, D., Comas, M., Vandorpe, T., Delivet, S., the MD194 shipboard scientists, 2013. EuroFLEETS Cruise Summary Report "MD194 GATEWAY", Cádiz (ES) - Lissabon (PT), 10-12 June 2013. Ghent University, Belgium, pp. 214.

Van Wambeke, F., Lefèvre, D., Prieur, L., Sempéré, R., Bianchi, M., Oubelkheir, K. Bruyant, F., 2004. Distribution of microbial biomass, metabolisms and factors controlling the bacterial production across a geostrophic front (SW Mediterranean Sea). Mar. Ecol.-Prog. Ser. 269, 1-15.

Vertino, A., Savini, A., Rosso, A., Di Geronimo, I., 2010. Benthic habitat characterization and distribution from two representative sites of the deep-water SML coral mound province (Mediterranean). Deep-Sea Res. II 57, 380-396.

Vertino, A., Stolarski, J., Taviani, M., Bosellini, F., 2014. Mediterranean corals: from Miocene to recent. In: Goffredo, S., Dubinsky, Z. (Eds.), The Mediterranean Sea: Its History and Present Challenges. Springer, pp. 257-274.

White, M., Mohn, C., de Stigter, H., Mottran, G., 2005. Deep-water coral development as a function of hydrodynamics and surface productivity around the submarine banks of the Rockall trough, NE Atlantic. In: Freiwald, A., Roberts, J.M. (Eds.), Cold-water Corals and Ecosystems. Springer, Berlin, pp. 503-514.

Wienberg, C., Hebbeln, D., Fink, H.G., Mienis, F., Dorschel, B., Vertino, A., López Correa, M., Freiwald, A., 2009. Scleractinian cold-water corals in the Gulf of Cádiz - first clues about their spatial and temporal distribution. Deep-Sea Res. I 56, 1873-1893. Zenk, W., Armi, L., 1990. The complex spreading pattern of Mediterranean water off the Portuguese continental slope. Deep-Sea Res. I 37, 1805-1823.

Zibrowius, H., 1980. Les Scleractiniaires de la Méditerranée et de l'Atlantique nord-oriental. Memoires de l'Institut Oceanographique. Monaco 11, 284. 